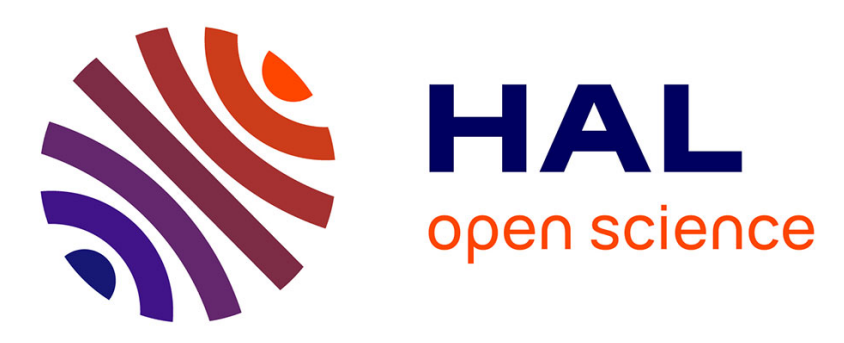

\title{
The Late Jurassic oblique collisional orogen of SW Japan. New structural data and synthesis
}

Michel Faure, Martial Caridroit, Jacques Charvet

\section{To cite this version:}

Michel Faure, Martial Caridroit, Jacques Charvet. The Late Jurassic oblique collisional orogen of SW Japan. New structural data and synthesis. Tectonics, 1986, 5 (7), pp.1089-114. 10.1029/TC005i007p01089 . insu-00716159

\section{HAL Id: insu-00716159}

\section{https://hal-insu.archives-ouvertes.fr/insu-00716159}

Submitted on 10 Jul 2012

HAL is a multi-disciplinary open access archive for the deposit and dissemination of scientific research documents, whether they are published or not. The documents may come from teaching and research institutions in France or abroad, or from public or private research centers.
L'archive ouverte pluridisciplinaire HAL, est destinée au dépôt et à la diffusion de documents scientifiques de niveau recherche, publiés ou non, émanant des établissements d'enseignement et de recherche français ou étrangers, des laboratoires publics ou privés. 
TECTONICS, VOL. 5, NO. 7, PAGES 1089-1114, DECEMBER 1986

THE LATE JURASSIC OBLIQUE COLLISIONAL OROGEN OF SW JAPAN. NEW STRUCTURAL DATA AND SYNTHESIS

Michel Faure, Martial Caridroit, and Jacques Charvet

Département des Sciences de la Terre, Universitê d'Orléans, France

Abstract. The structural configuration of SW Japan mainly reflects a late Jurassic-early Cretaceous orogeny. The region is divided into an inner belt and an outer belt, on the Japan sea and Pacific ocean sides respectively, by a strike-slip fault, the Median Tectonic Line (MTL). Both consist of a series of stacked nappes. The inner belt is divided into a Jurassic olistostrome known as the Tanba zone and a hinterland area comprising continental Triassic-Jurassic sediments. The Tanba zone is sliced into two units: a lower one with late Jurassic matrix and Triassic-early Jurassic radiolarite olistoliths, tectonically overthrust by an upper unit comprising an olistostrome with middle Jurassic matrix and blocks which include late Paleozoic limestone, basic lava, and radiolarite. The Tanba zone is overthrust by a Paleozoic nappe complex derived from the hinterland. The basal sole of the nappe corresponds to a peculiar unit called the ultra-Tanba zone. In the Chugoku area, the hinterland is divided into an upper nappe: the Oga nappe, formed by PermoCarboniferous limestone and Permian clastic rocks and a lower one: the Sangun-Maizuru nappe, formed by Paleozoic

Copyright 1986

by the American Geophysical Union.

Paper number $6 \mathrm{T0398.}$ 0278-7407/86/006T-0398\$10.00 high pressure (HP) metamorphics (the Sangun schists), the Permian Maizuru olistostrome, and the dismembered Paleozoic Yakuno ophiolites. In the northern part of SW Japan, the Tanba zone is in faulted contact with the circumHida and the Hida zones. The former is interpreted as the equivalent of the Oga and Sangun-Maizuru nappes of the Chugoku domain crushed by post Cretaceous tectonics. The latter consists of Paleozoic high temperature (HT) metamorphic rocks and late Triassic-early Jurassic granite, locally mylonitized and covered by early Jurassic sandstone. The outer belt is formed by a superficial nappe similar to the Tanba zone thrust upon a "deep domain" characterized by a synmetamorphic ductile deformation. The "deep domain" is divided into a lower unit, the Oboke unit formed by continental derived arenites and a Green Schist nappe consisting of oceanic sediments and resedimented ophiolites. The Green Schist nappe overthrusts the oboke unit under synmetamorphic conditions with an eastward displacement. The two belts are separated by the Ryoke zone which corresponds to the southern part of the Tanba zone affected by a Cretaceous HT metamorphism and sharply cut by the MTL. A geodynamic model is proposed for the Jurassic orogeny of SW Japan assuming that the evolution of the inner and outer belts are linked. In the Late TriassicEarly Jurassic SW Japan is an active 


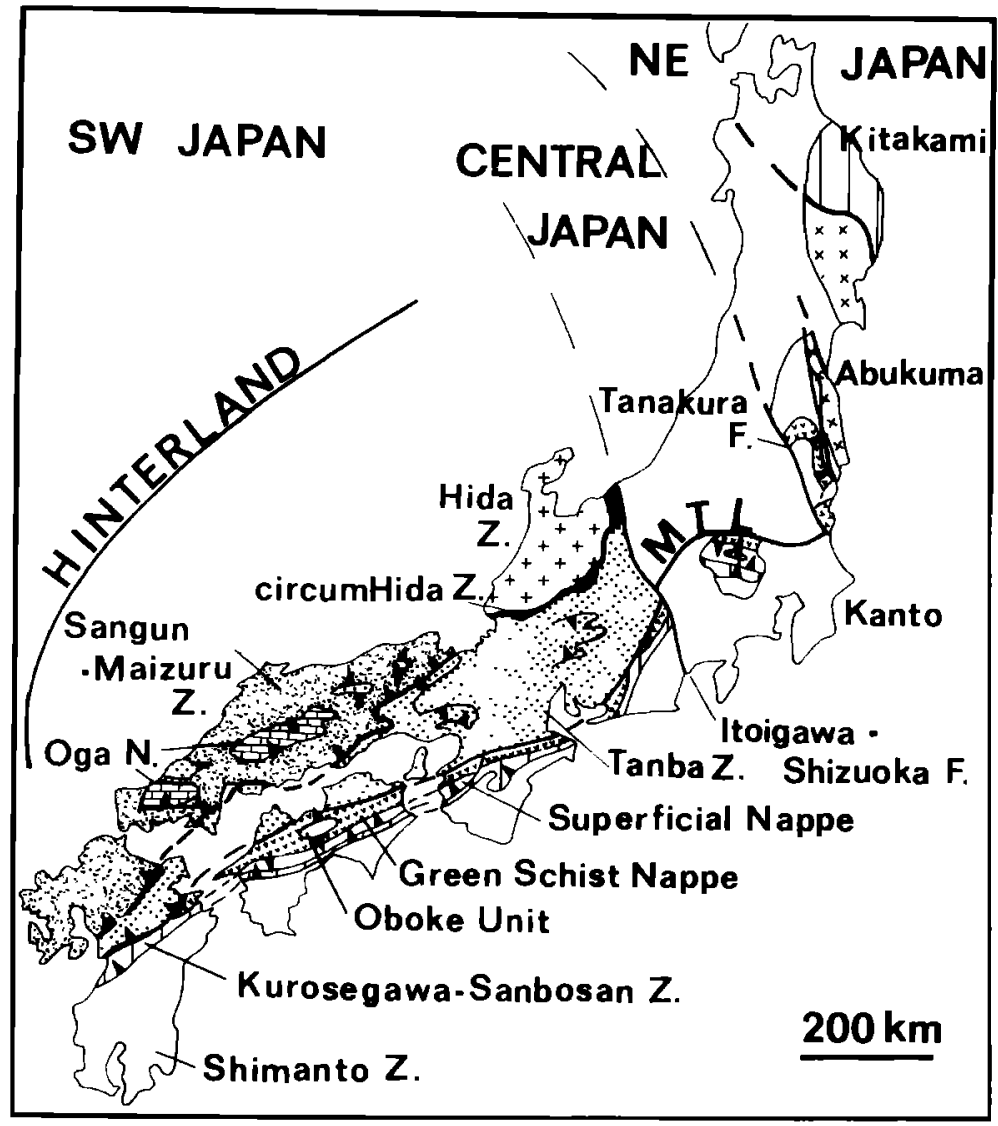

Fig. 1. Structural map of Japan, except Hokkaido, with emphasis on the late Jurassic structure. The distinctions between $S W$, Central, and NE Japan are Tertiary divisions due to the Tanakura and the Itoigawa-Shizuoka faults.

plate margin. The upper plate or South China block consisted of the hinterland and the Tanba belt, a forearc basin; the lower plate consisted of an oceanic area and the South Japan continent. The basic mechanism of the orogeny is ascribed to the oblique subduction and collision of the South Japan continent.

\section{INTRODUCTION}

The Japanese Islands can be divided into three domains by means of Cretaceous and younger faults (Figure 1), namely : (1) NE Japan north of the Tanakura fault, (2) Central Japan between the Tanakura and Itoigawa-Shizuoka faults, (3) SW Japan south of the Itoigawa-Shizuoka fault. This last domain is also divided by a large strike-slip fault, the Median Tectonic Line, into an inner belt on the Japan Sea side and an outer belt on the Pacific Ocean side. However, though this geographic division can be used to explain the Miocene and younger features of Japan such as the opening of the Japan Sea, the collision of the Izu peninsula, and the present plate tectonic framework, it cannot be used to describe older deformations responsible for the progressive development of the present Japanese Islands since Paleozoic times. It is now a widely accepted fact that the pre-Miocene structure of Japan is a result of three main orogenic cycles bounded by regional unconformities (e.g., Kobayashi, 1941; Kimura, 1973; Tanaka and Nozawa, 1977). From youngest to oldest they are:

1. A Paleogene cycle or Shimanto orogeny responsible for the deformation of the outermost zone of SW Japan (the Shimanto zone), for the reworking by brittle, superficial and local reverse faults of the older zones and for a calcalkaline magmatism related to the subduction of an oceanic plate under the islands.

2. A Mesozoic cycle equivalent to the early stage of the Sakawa orogeny of $T$. 
Kobayashi (1941). It begins in the late Triassic and ends in the middle Cretaceous when the nappe structures are sealed in the outer belt by shallow-water Neocomian deposits and in the inner belt by middle to late Cretaceous acidic volcanism or continental Cretaceous deposits or are intruded by late Cretaceous-Paleogene granitoids. The deformation related to this cycle reaches its climax in late Jurassic-early Cretaceous times with the emplacement of large nappes. It corresponds chronologically to the Daebo orogeny of Korea (e.g., Reedman and Um, 1975) and the early Yenshan deformations in China (e.g., Klimetz, 1983).

3. A late Paleozoic-early Triassic cycle or Akiyoshi orogeny (Kobayashi, 1941) that very little is known about, since it is largely reworked by the early Yenshan orogeny.

When considering the early Yenshan orogeny, the inner-outer division must not be equated with the inner-outer distinction of the alpine fold belt of Europe where the inner belt is characterized by intensely deformed metamorphic rocks and the outer belt by more superficial tectonics. The innerouter division of SW Japan will be used here as it is a convenient division.

The early Yenshan orogeny is not restricted to SW Japan. The Kanto area of Central Japan (Figure 1, Kimura, 1973; Tanaka and Nozawa, 1977; Guidi et al., 1984) is very similar in stratigraphy and structure to the outer belt of SW Japan. In NE Japan also, the Kitakami and Abukuma massifs can be compared with the Sanbosan zone, the Kurosegawa zone and the Green Schist nappe of SW Japan (Figure 1, Kimura et al., 1975; Faure, 1985a).

This paper aims to present a new and comprehensive structural map of the Jurassic orogen of Southwest Japan, based on a detailed description of selected key areas and a synthesis of previous works. It then attempts to gather all the available data into a new geodynamic model.

THE GEOLOGICAL STRUCTURE OF THE INNER BELT

\section{General outline}

The inner belt is classically subdivided into several zones roughly trending east-west (Kimura, 1973; Tanaka and Nozawa, 1977). The main subdivisions considered in this paper are: (1) the Tanba zone and (2) the hinterland including all the other zones except the Ryoke zone. This last one is considered separately, since the post-Jurassic deformation and magmatism are by far predominant. Inside the hinterland there is a distinction between the Chugoku domain on one hand and the Hida-circumHida domain on the other hand. This distinction is due merely to present geographic conditions, since their relationships are hidden under the Japan Sea. In the following the geology of the Tanba zone, Chugoku domain, and Hidacircum-Hida domain is described with emphasis on Jurassic structure.

\section{The Tanba zone}

The Tanba zone is the largest one of SW Japan (Figures 1 and 2) well developed around Kyoto, i.e., the Tanba area sensu stricto and North of Nagoya, i.e., the Mino area. Recent sedimentological studies and discoveries of radiolaria fossils in siliceous pelite, chert, and mudstone (e.g. Yao, 1972; Tanba Belt Research Group, 1979; Mizutani et al., 1981) show the importance of the olistostrome phenomenon. The Tanba zone should be now considered as an area of Jurassic chaotic sedimentation. Turbidites, diamictites, and olistostromes are conspicuous facies in the zone, and almost all of the radiolarian chert, limestone, and basic volcanic are olistoliths. Local but precise biostratigraphic studies suggest the existence of nappes, for instance, in the Kyoto area and up to the Japan sea (Figures 2 and 3; Imoto et al., 1981; Ishiga, 1983; Caridroit et al., 1984, 1985) or North of Nagoya(Kano, 1979) and perhaps south of the circum-Hida zone (Adachi and Kojima 1983).

As the Kyoto area is the best known, it is given here as an example. There, the lowermost unit observed in the core of the anticlines consists of an olistostrome whose siliceous siltstone and black shale parts of the matrix yield late Jurassic radiolaria. The olistoliths are exclusively well bedded cherts ranging from middle Triassic to early Jurassic in age (Isozaki and Matsuda, 1980). The lowermost member of the apparent sequence is often a large middle Triassic bedded chert mass but, it is probably a huge olistolith. Thus the base of the sequence is unknown.

The upper unit consists of late 


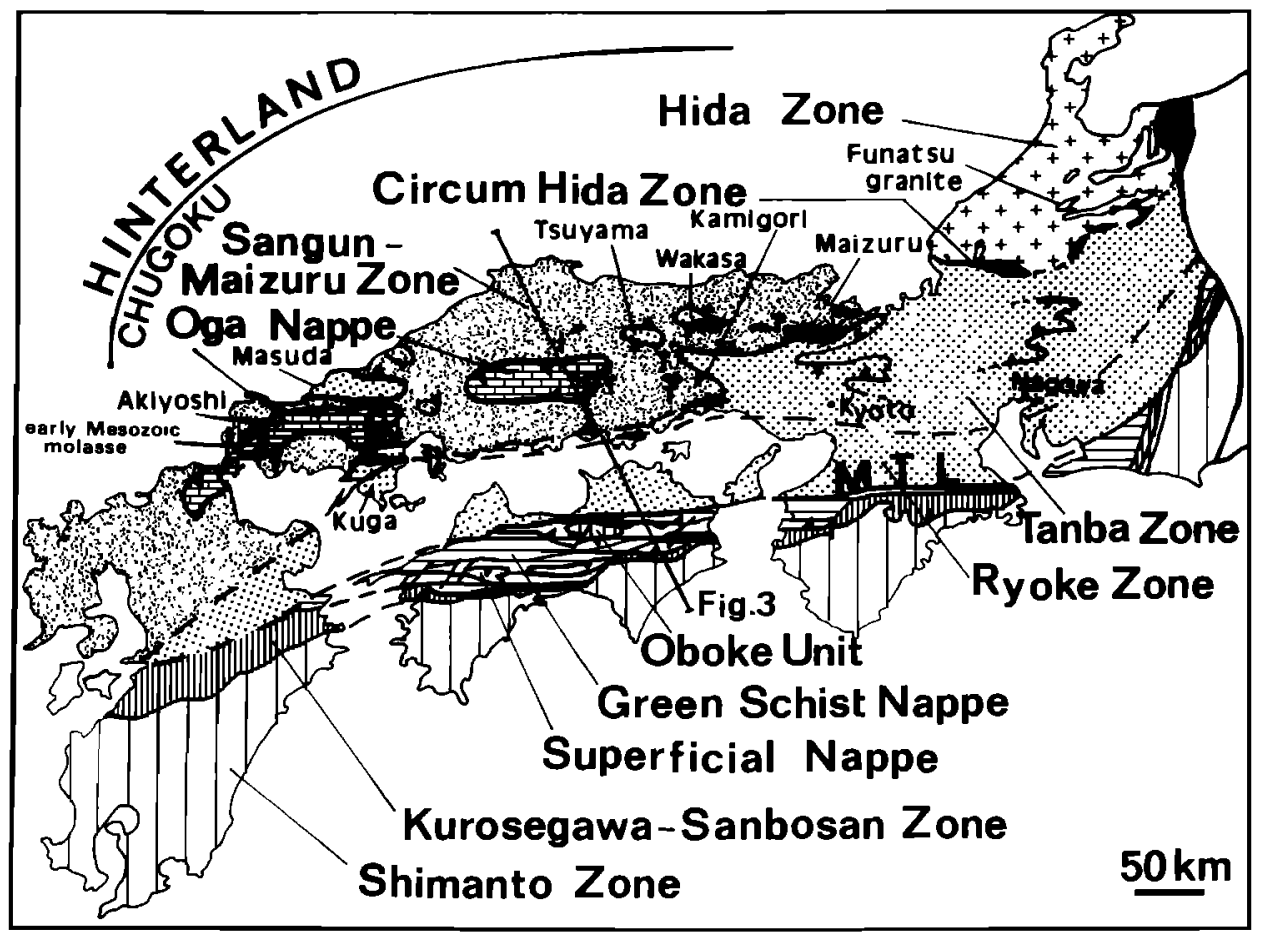

Fig. 2. Schematic map of the Late Jurassic orogen in SW Japan. The Cretaceous and younger rocks have been omitted.

Carboniferous to early Permian red-brown chert, Permian hyaloclastite, and basic lava sometimes having pillow structures, dated by fusulina found in the interlayered limestone. These rocks are overlain by an early to middle Jurassic olistostrome. Permo-Carboniferous and Triassic cherts, Permian basic volcanoclastic rocks, and Permo-Carboniferous limestones are included as olistoliths. The chaotic formation is followed by a sandstone formation characterized by slump structures and turbiditic alternations. In places, interstratified reworked granite, acidic lava and tuff conglomerates are known. It should also be noted that plagioclase and rock fragments derived from acidic and calcalkaline rocks are conspicuous (Shimizu et al., 1978). As for the lower unit, the true stratigraphic succession is unknown. According to Ishiga (1983), Permian chert forms the base of the sequence followed by the greenrock of the same age, it is conformably overlain by the early-middle Jurassic olistostrome followed by the turbiditic sandstone. However, Permo-Carboniferous greenrock and chert may also be kilometer-scale olistoliths reworked into the early to middle Jurassic matrix. Nevertheless, it is clear that early to middle Jurassic black shale, sandy mudstone, tuffaceous shale, and diamictite overlies similar but younger facies demonstrating the existence of at least one late Jurassic tectonic superposition.

olistostrome and nappe structure were already recognized in the eastern part of the Tanba area, north of Nagoya (Figure 2) by Kano (1979) on the grounds of sedimentological studies. The "nappes" consist of kiloneter-scale Triassic chert slabs surrounded by olistostromes which are interpreted as collapse structures in front of the advancing nappes. They are synsedimentary gravity-driven structures, assumed to have slid from south to north. The origin of the gravity sliding is thought to be the uplift of the Ryoke zone. This is in apparent contradiction with the nappe motion in the Kyoto area, which is from NW to $S E$, at least in the late stages. In fact, the two sets of nappes differ in timing and emplacement mechanism. The nappes of the eastern Tanba zone are early (circa middle to late Jurassic) synsedimentary structures, 


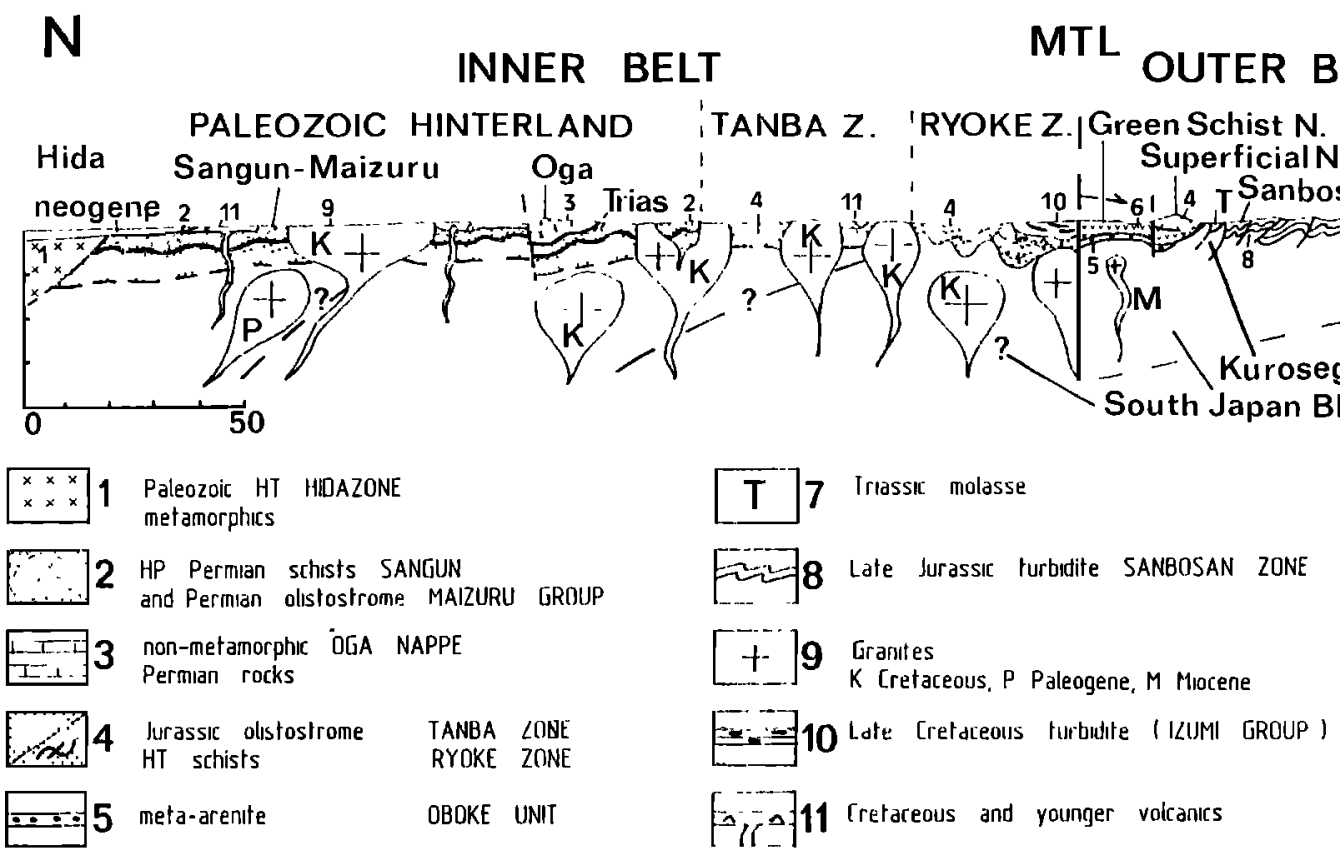

6 Jurassic HP Schist GREEN SCHIST NAPPE

Fig. 3. General N-S cross section in the upper crust of SW Japan. (A) Neogene and Quaternary deposits, (B) Cretaceous-Tertiary volcanism, (C) Intrusive granitoids ((K) Cretaceous, (P) Paleogene, (M) Miocene), (D) Neocomian molasse in the outer belt, (E) Maestrichtian turbiditic (Izumi group) on the northern side of the MTL, (F) Cretaceous HT metamorphic rocks and anatectic granitoids Ryoke zone, (G) Late Jurassic and Cretaceous-Paleogene turbidite in the Sanbosan and the Shimanto zones, respectively, (H) Paleozoic HT Hida metamorphics, (I left Paleozoic HP Sangun metamorphics, right serpentinite, (J) Paleozoic ophiolite (Yakuno complex), (K) Permian Maizuru olistostrome, (L) Oga nappe, left, Late Carboniferous-Middle Permian reefal limestone facies, right, Late Permian noncalcareous facies, (M) Triassic sandstone, (N) Jurassic Tanba olistostrome and its extension in the superficial nappe of the outer belt, (O) Oboke sandstone unit, (P) Green Schist nappes undifferentiated, ( $Q$ ) Basement of the outer belt (South Japan block) outcropping in the Kurosegawa zone. The deep crustal structure is from Hada et al.1982, 6.1 and 7.8 are the layer velocities in kilometers per second.

while the nappes of the Kyoto area are later ones formed after rock induration. Moreover, the sense of displacement of the eastern Tanba zone is not firmly concluded from microtectonic observations.

West of the Kyoto area, Tanba type facies outcrops in several places, namely; the Masuda and Kuga (Figures 4, and 7C), Kuse (Figure 6), Kamigori and Wakasa areas, (Figures 5 and 7A; Toyohara 1977; Tanaka,1980; Hayasaka and Hara, 1982; Hayasaka et al.,1983; Faure and Caridroit, 1983). They are interpreted here as tectonic windows inside the hinterland (Figures 1 and 2) but the two units of the Kyoto area are not definitely recognized owing to the small surface of exposure.

Several problems remain with the Tanba zone, among them, the source area of the olistoliths, the environment and depositional conditions of the siliceous facies, and the nature of the underlying crust. The Tanba zone is generaly considered by previous workers, to be an oceanic area whose crust has disappeared by subduction under the Hida zone; the sediments were accreted along the Hidacircum-Hida margin (Chihara and Komatsu, 


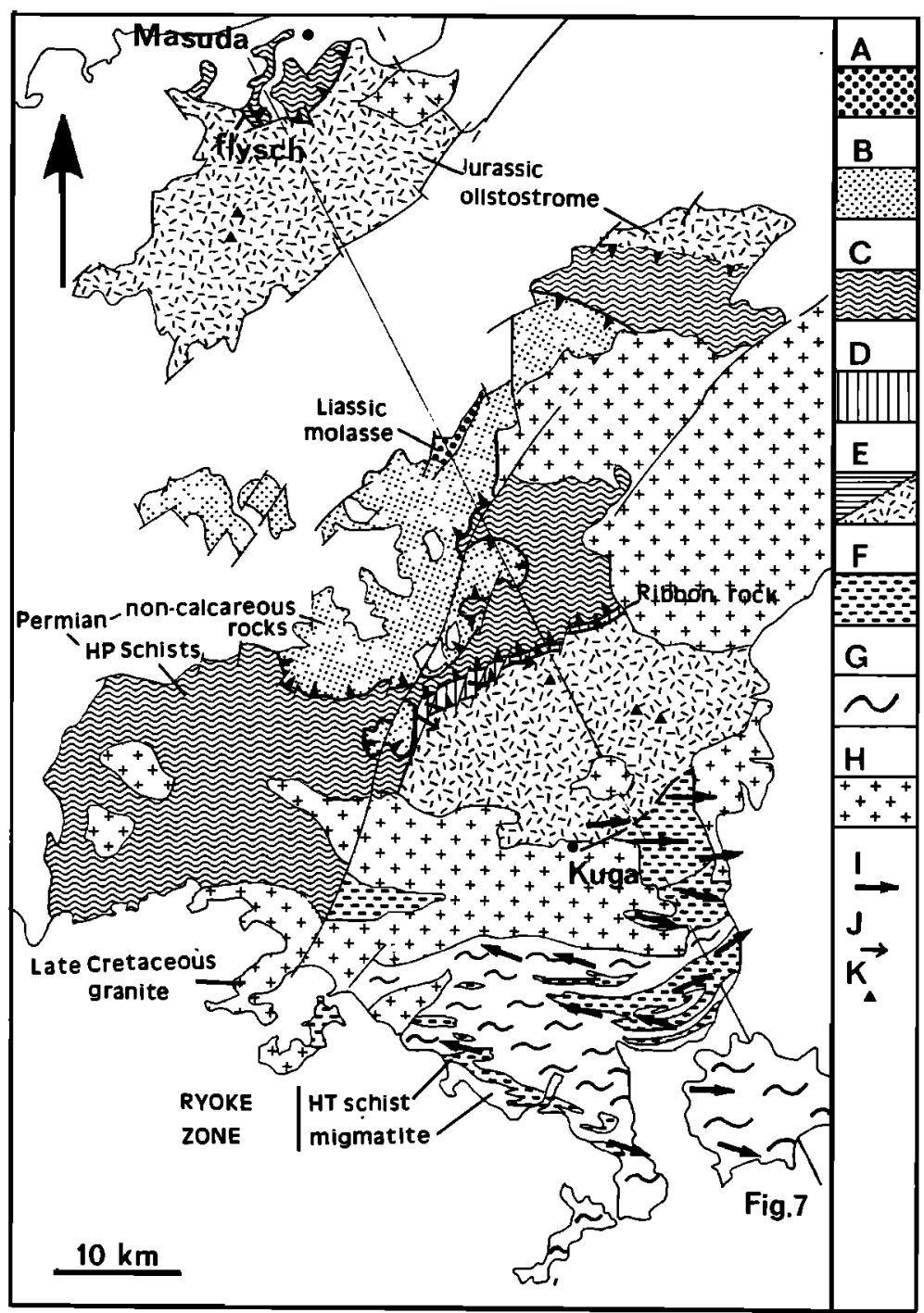

Fig. 4. Structural map of the Kuga-Masuda area, modified from the $1 / 50000$ geological map of the Nishikigawa area. (A) Liassic molasse, (B) Noncalcareous Paleozoic rocks of the Oga nappe, (C) HP Sangun metamorphics, (D)ribbon facies, (E left) flysch facies, (E right) Jurassic olistostrome, (F)Southern part of the Tanba olistostrome transformed into biotite-sillimanite schist by the HT Ryoke metamorphism, (G) Cretaceous Ryoke migmatite granite, (H) Late Cretaceous granite, (I) Mineral and stretching lineation in the Ryoke metamorphics, arrows indicating the plunge, $(\mathrm{J})$ Mineral and stretching lineation in the ribbon rock facies, arrows indicating the sense of shear, (K) Location of the Jurassic radiolaria in the matrix of the olistostrome, from Hayasaka et al. (1983).

1981; Hattori, 1982; Hara, 1982; Mizutani and Hattori, 1983; Hirooka et al., 1983). However, those models proposed for the eastern part of the Tanba zone cannot account for the Chugoku area.

The source of the Paleozoic olistoliths can be easily found into the hinterland. The limestones are probably derived from the Oga nappe, since they have the same age and facies. The basic rocks can be provided by the Yakuno complex or the Carboniferous rocks at the base of the Oga nappe. This is in agreement with Adachi and Kojima's (1983) 


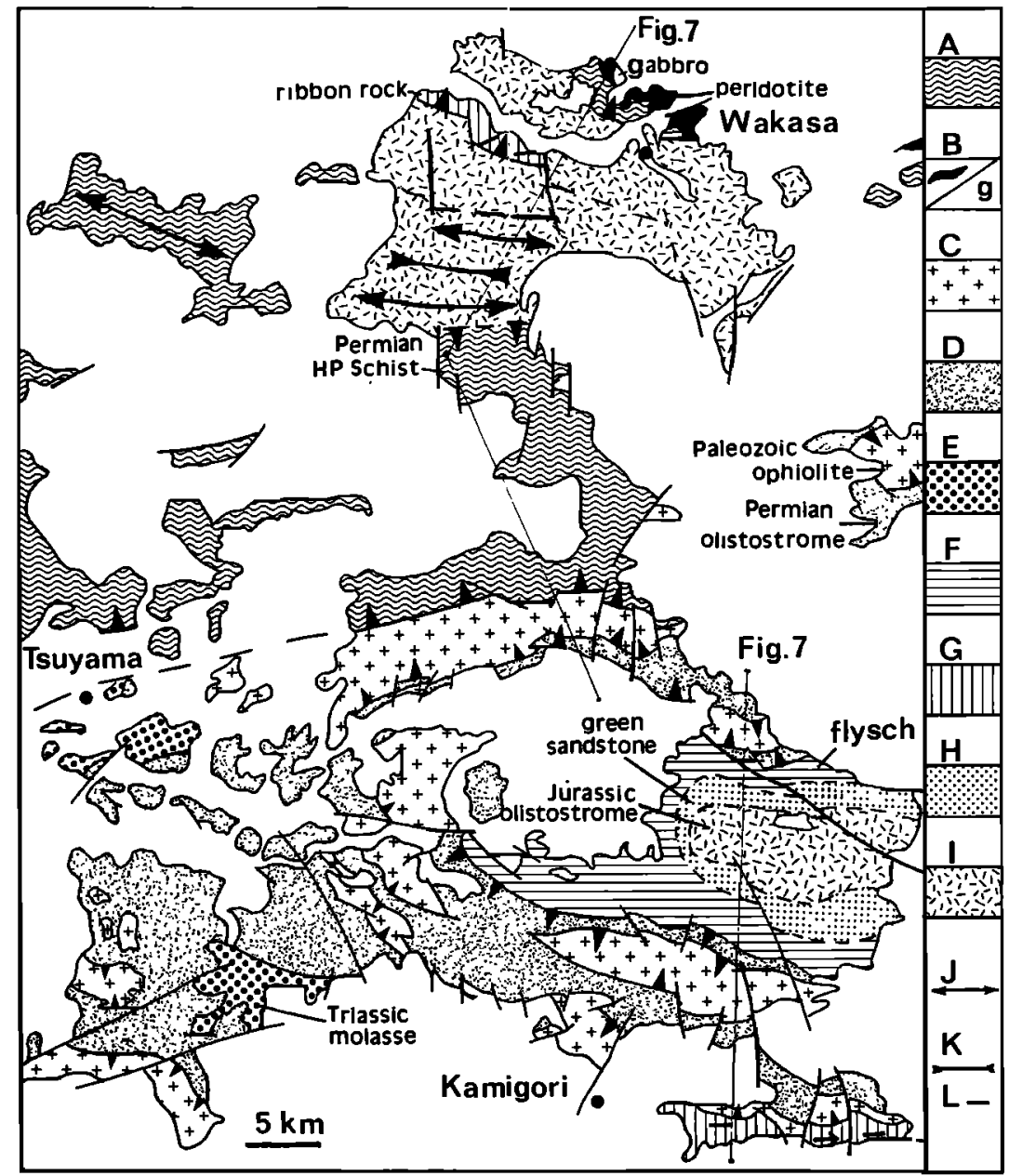

Fig. 5. Structural map of the Kamigori-Wakasa area, adapted from the $1 / 50000$ geological maps of Wakasa, Chizu, Sayo, and Kamigori, (A) Sangun metamorphics, (B left) serpentinized peridotite, (B right) metagabbro, (C) Paleozoic ophiolites, (D) Permian Maizuru olistostrome, (E)Triassic molasse, (F\&G) Ultra Tanba zone, (F) Flysch (Triassic?), (G) Ribbon rock, (H\&I) Tanba zone, (H) Greenish sandstone, (I) Jurassic olistostrome with Permo-Triassic olistoliths, (J) Antiform, (K) Synform, (L)Mineral and stretching lineation in the ribbon rock facies arrows indicating the sense of shear.

suggestion that the limestone olistoliths in the eastern part of the Tanba zone were derived from the circum-Hida zone, which is the extension of the Chugoku area in our interpretation. Biotitesillimanite gneiss, garnet gneiss, marble, orthoquartzite, granite, quartz porphyry andesite, Permo-Carboniferous limestone are found as pebble in conglomerate. Isolated heavy minerals as such as sillimanite, garnet, and chloritoid are conspicuous in sandstone (Adachi, 1971; Adachi and Kojima, 1983).
Biotite-sillimanite gneiss provides Precambrian ages, (circa 1500 and 1700Ma, Shibata, 1979), unknown in the Hida zone but widespread in Korea and China (Reedman and Um, 1975; Lee, 1980). Sandstone in the Tanba zone contains seams of carbonaceous matter (Iijima et al., 1978) or plant fragments (Nishida et al., 1974). Most of this detritus was provided from the Hida zone where such rock and fossils are recognized.

The cherts are often interpreted as deep pelagic ocean deposits in most of 
the geodynamic models. However, according to sedimentological and geochemical comparisons with present oceanic siliceous ooze, the Triassic-early Jurassic Tanba cherts are considered to be deposited in an offshore or marginal sea environment (Imoto and Fukutomi, 1975; Shimizu and Masuda, 1977; Sugisaki et al., 1982; Matsumoto and Iijima, 1983). With reference to the basement problem of the Tanba zone, it is necessary to distinguish between the present basement formed by late Cretaceous-Paleogene granite, the postorogenic basement and the preorogenic basement. As for the former, it will be discussed with the geodynamic model. As for the latter, there is only one locality in the northern part of the Tanba zone, where pillow lava and basic tuffs are closely associated with middle Triassic-early Jurassic pelite and chert (Hattori and Yoshimura, 1983). Except this place, there is no evidence for Mesozoic ophiolite, even reworked in the whole Tanba basin. Thus it is necessary to suppose either that all the oceanic crust has been subducted or that it was very limited in extension and perhaps never existed.

\section{The Hinterland}

This is a wide and composite domain, but in terms of the Jurassic orogeny, the characteristic feature is that all the constituent zones of the hinterland suffered to varying degrees the late Paleozoic orogeny and are unconformably overlain by shallow water facies of late Triassic to middle Jurassic age (Figures 1,2 and 8). Thus during the Jurassic orogeny the hinterland behaves as an already structured "basement". Since the relationships between the two parts of the hinterland, the Chugoku domain and the Hida-circum-Hida domain are hidden under the Japan sea, both areas are presented separately.

The Chugoku domain. Owing to widespread extent of the Cretaceous and younger formations, the Jurassic and older rocks outcrop only by patches. Since this paper discusses the late Jurassic orogeny, Triassic-Jurassic detrital rocks and their deformation, the stacking of nappes of the Chugoku zone with reference to the late Jurassic structure and the relationships between the Chugoku domain and the Tanba zone are successively presented.
The Triassic-Jurassic molasse facies: The early Mesozoic rocks which form limited outcrops all along the Chugoku domain, from Maizuru to Akiyoshi (Figures 2,4 , and 6) correspond to the post orogenic molasse of the Paleozoic cycle. They are shallow water sediments containing brackish water, lacustrine and deltaic facies; coal seams and plant fossils are conspicuous (Nakazawa and Shiki, 1954; Teraoka, 1959; Tanaka and Nozawa, 1977). The Rhaetic-Liassic flora is similar to those known in China, Korea and Sikhote Alin (Kimura, 1980). The early Jurassic formations of the Chugoku area are correlated with the Kuruma group of the circum-Hida zone upon the base of similar biofacies and lithofacies (Tanaka and Nozawa, 1977; Yu, 1983).

All these formations are considered to unconformably cover the Paleozoic rocks (e.g., Kobayashi, 1941; Nakazawa and Shiki, 1954; Teraoka, 1959; Kimura, 1973). However, the very unconformity is seldom observed, as it is often hidden by subvertical faults and sometimes has been developed as a thrust plane since it corresponds to a mechanically weak zone. The latter is the case in the Oga area, (Figures 6 and 7B), where the basal conglomerate and sandstone overlying the Sangun schists suffered a brittle deformation marked by tension gashes, slickensides, Riedel planes, and crushed zones localized along high-angle reverse faults directed southwestward.

The early Mesozoic rocks are never metamorphosed nor schistosed, but very often they bear the marks of a weak superficial deformation in the form of reverse faults and open folds. In the Tsuyama area (Kawai, 1958; Mitsuno and Omori, 1964), the Triassic sandstone lies in the core of overtuned synclines. In the Oga area (Figure 9), low angle southward verging brittle shear zones associated with drag folds are conspicuously observed in the Triassic sandstone overthrusted by the Oga nappe. Moreover, the age of the deformation is not clearly defined, since the early Cretaceous rocks also are sometimes affected by reverse faults, for instance, in Oga or Kamigori areas (Faure and Caridroit, 1983). North of Tsuyama (Figure 6) the Sangun metamorphic rocks thrust up the Miocene conglomerate with a very steep (circa $70 \mathrm{~N}$ ) reverse fault, (Kawai, 1958; Faure and Caridroit, 1983). Synsedimentary normal faults are observed in the Maizuru, Oga, and 


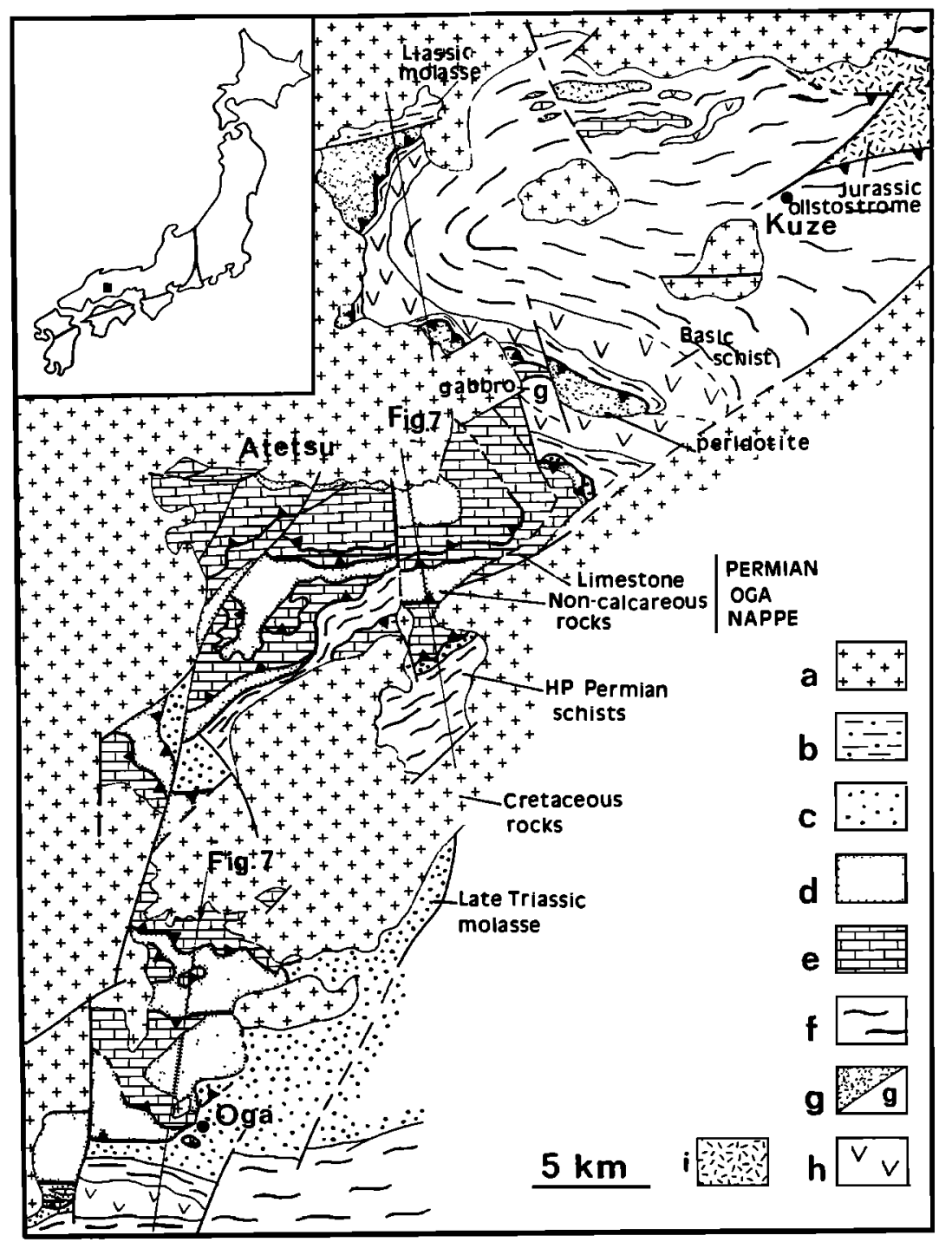

Fig. 6, Structural map of the Oga-Atetsu area, (a) Cretaceous and younger granite, pyroclastites, and sediments, (b) Liassic molasse, (c) Late Triassic molasse, (d\&e) Oga nappe, (d) Late Permian noncalcareous facies, (e) Late Carboniferous-Middle Permian reefal limestone facies, (f) Permian Sangun metamorphics, (g) serpentinized peridotite, ( unshaded g) metagabbro, (h) Basic schists into the Sangun metamorphics, (i) Jurassic olistostrome.

Akiyoshi areas at the outcrop and microscopic scales (Figure 10). These data fit well with the Triassic distension inferred in our model.

The stack of Paleozoic nappes: The Chugoku domain has been interpreted by early workers as being formed by nappes and recumbent folding. Kobayashi (1941) defined the late Paleozoic Akiyoshi orogeny in the westernmost part and the late Jurassic-early Cretaceous Oga nappe in the central part. In agreement with
Hase (1964), field surveys in the KugaMasuda area (Figure 4), Kamigori-Wakasa area (Figure 5) and Oga-Atetsu area (Figure 6) allows the subdivision of the Chugoku domain into the Oga nappe, the Sangun metamorphics, the Yakuno ophiolite, and the Maizuru zone. The last three are not differentiated in Figure 2. The Oga nappe is the uppermost unit. It comprises non metamorphic Iimestones and noncalcareous sediments ranging from late Carboniferous to late Permian. The age of 


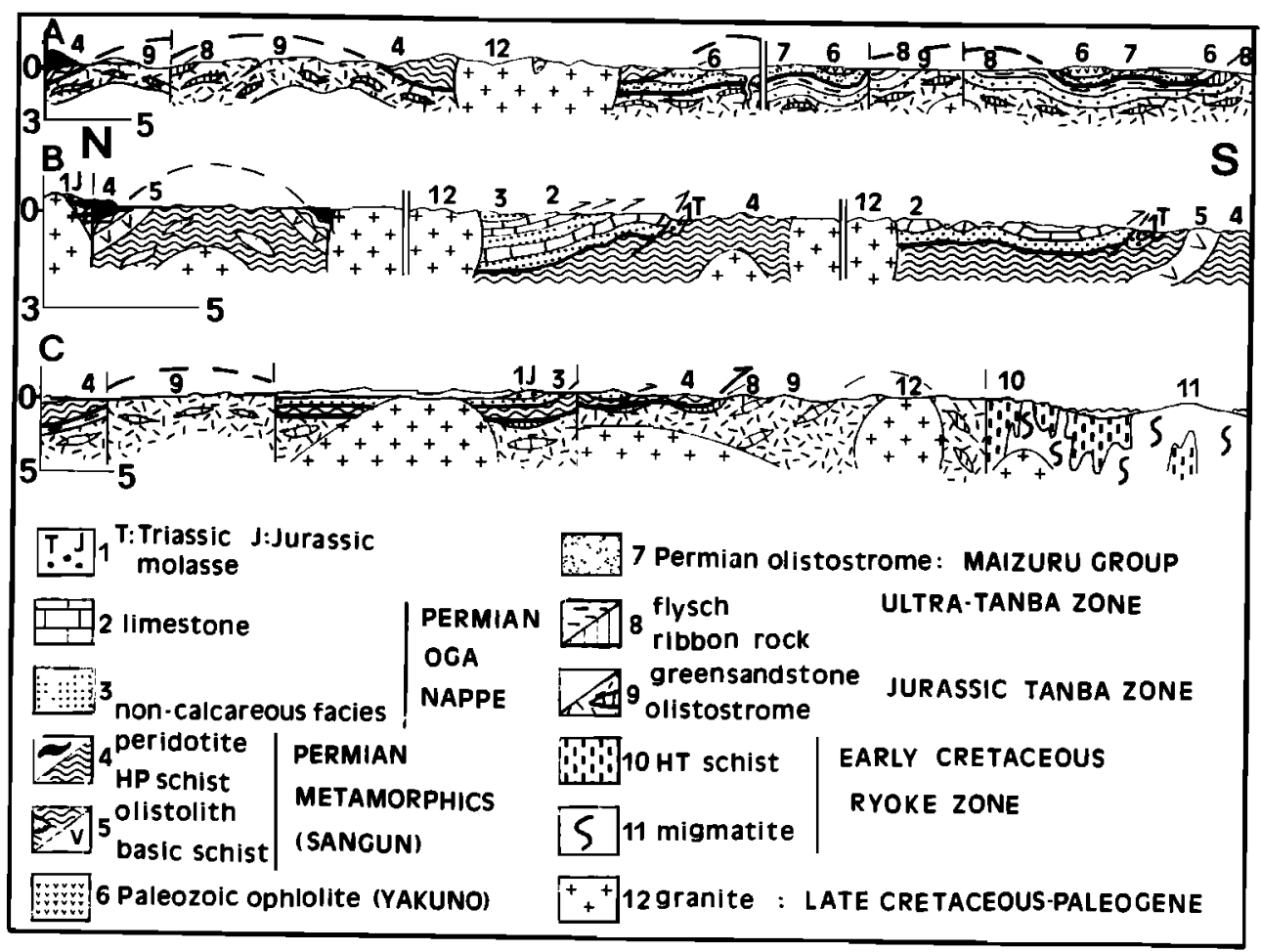

Fig. 7. Submeridian cross sections, (A) Kamigori-Wakasa area, (B) Oga-Atetsu area, (C) Kuga-Masuda area. See Figures 4, 5, and 6 for location.

the Oga nappe is a debated question. In the Oga area, the Triassic rocks unconformably overlie both the Oga nappe and its substratum of Sangun metamorphic rocks (Teraoka, 1959; 0to, 1984; Figure $6)$. However, a deformation surely occurred between the late Triassic and middle Cretaceous, since in the Oga and Atetsu areas the Paleozoic rocks thrust the Triassic sandstone which is folded and overturned (Figure 9). A two stage deformation can account for the contradictory observations. At first, between late Permian and late Triassic times the Oga nappe thrusts the Sangun metamorphic rocks, then the contact is covered by the Triassic deposits and during the late Jurassic orogeny, the Oga nappe moves again overthrusting the Triassic deposits. In discussing the Jurassic orogeny, there is a need to estimate the amplitude of the Jurassic thrust. It could be a multikilometer scale overthrust of a minimum of $100 \mathrm{~km}$ assuming a displacement perpendicular to the regional NE-SW trend, since there is no room for a root zone before the circum-Hida zone, or only a limited high angle thrust. This second interpretation is preferred (Figure 7C) given that in the Akiyoshi area the Triassic formations are covering basal contact of the Oga nappe (Sakamoto, 1969; Tanaka and Nozawa, 1977).

As already stated, the Sangun metamorphics are relevant to the Paleozoic orogeny; however, they suffered a reworking during the late Jurassic as shown by the $\mathrm{K}-\mathrm{Ar}$ ages clustering about $260 \mathrm{Ma}$ and $170 \mathrm{Ma}$ (Shibata and Igi, 1969; Nishimura, 1981; Nishimura et al.,1983). North of Kamigori (Figures 5 and 7A) the Sangun metamorphics thrust up the Yakuno ophiolite developing decameter scale drag folds. The Yakuno ophiolite in turn thrusts a Permian olistostome called the Maizuru group (Faure and Caridroit, 1983; Caridroit et al., 1984, 1985). The Triassic molasse, when it is present, is always trapped between late subvertical faults, so that a Jurassic age for the thrust cannot be ascertained. The Maizuru group is the lowermost part of the hinterland stack of nappes, it thrusts up the Tanba zone by means of a complex basal sole which is described in the following section.

The relationships between the Paleozoic 


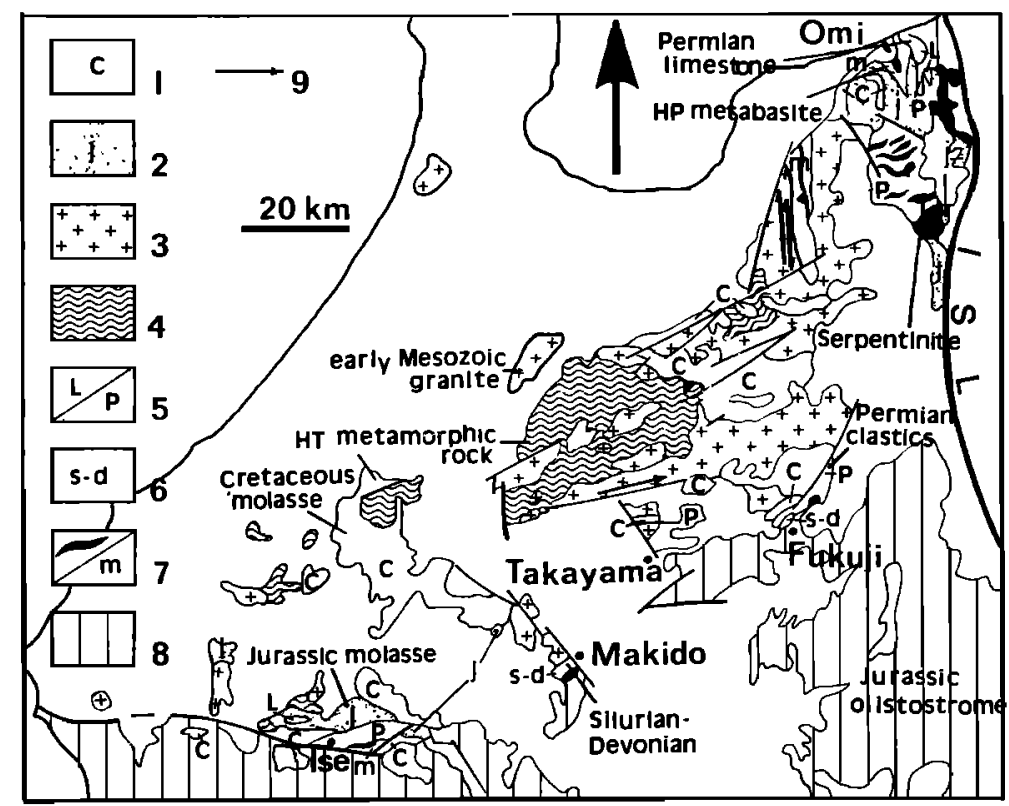

Fig. 8. Structural map of the Hida-circum-Hida domain, (1) Cretaceous molasse, (2) Jurassic molasse, (3) Early Mesozoic Funatsu granite, arrows indicating the sense of shear into the mylonitic facies, (4) Paleozoic Hida HT metamorphics, (5 P) Nonmetamorphic Permian rocks, (5L) limestone facies of Omi and Ise, (6) Nonmetamorphic Siluro-Devonian rocks, (7) Metamorphic rocks of the circum-Hida zone, (left) Serpentinite; (right) early Paleozoic metabasites sometimes with HP assemblages, (8) Jurassic olistostrome (Tanba zone), (9) lineation in the granite mylonite with the sense of shear.

rocks and the Jurassic Tanba zone: It is in the Maizuru zone that the relationships between the Jurassic Tanba zone and the Paleozoic rocks are the best known (Caridroit et al., 1984, 1985). The two units of the Tanba zone defined in the
Kyoto area are recognized, but the upper unit is overlain by another one called the ultra-Tanba zone. Upwards, the cross section is as follows: The early to middle Jurassic olistostrome is covered by greenish sandstone; it is thrusted by
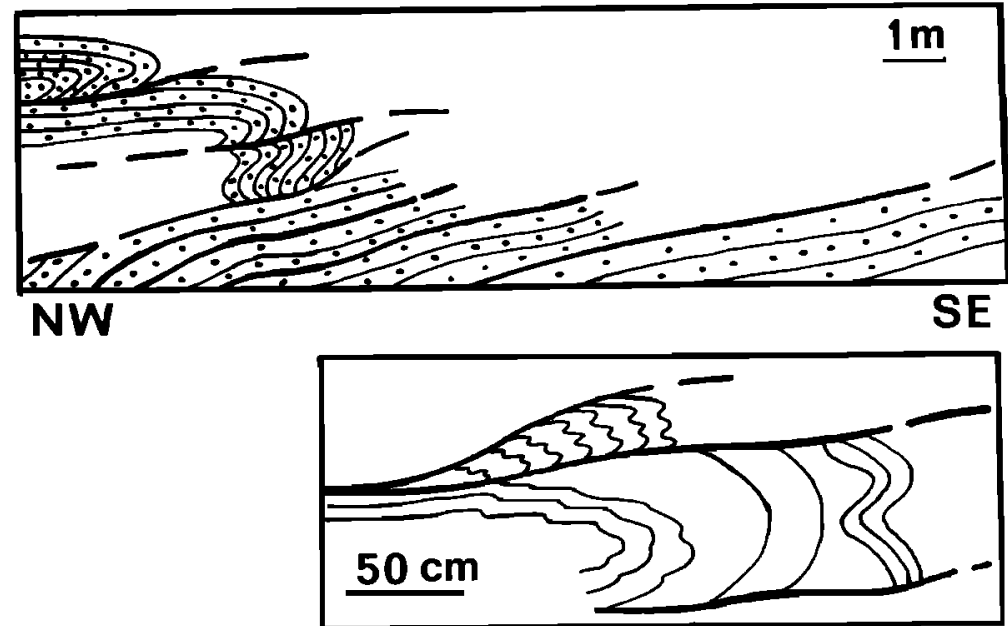

Fig. 9. Deformation of the late Triassic sandstone, below the Oga nappe near Oga. 


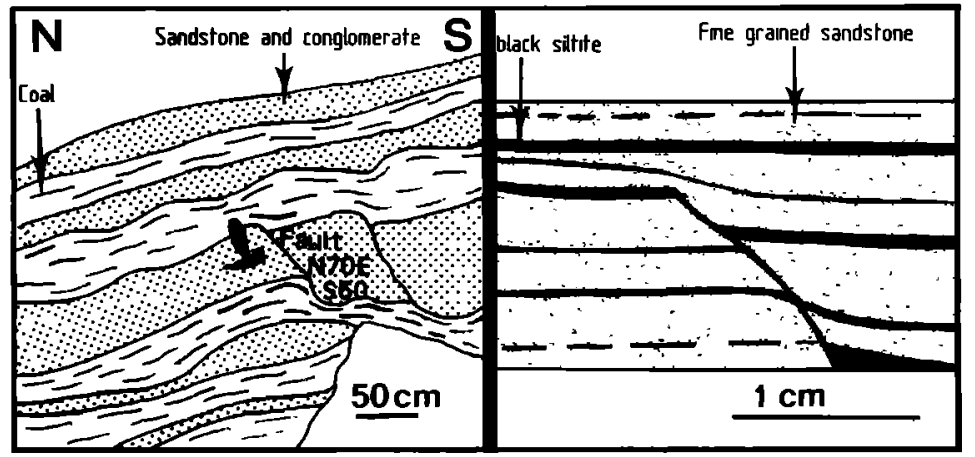

Fig. 10. Example of synsedimentary faulting in the Triassic molasse.

a late Permian cherty formation called the "ribbon facies" because chert and pelite form millimeter-scale alternations. The ribbon facies is followed by a flyschoid formation assumed to be early Triassic. It is itself covered by an olistostrome assumed to be early to middle Jurassic since it resembles the olistostrome of the Tanba upper unit. The ultra-Tanba zone is in turn thrusted along late Permian black pelite belonging to the Maizuru group. The ribbon facies and the flysch are characteristic formations. They have been recorded in the Kuga and Masuda areas (Figure 4), in the Kamigori and Wakasa areas (Figure 5), in the Kuze area (Figure 6 ), and other small places (Figure 2). The Chugoku area forms in its entirity a vast nappe overlying the Tanba zone. The ultra-Tanba zone appears as the sole of this nappe where almost all strain is concentrated. The bedding surfaces of the flysch are coated by neoformed white micas and chlorite, and the ribbon facies is extensively recrystallized. The initial bedding of the ribbon facies is enhanced by a spaced cleavage formed by alternation of polycrystalline quartz bands and micaceous layers. The same anastomosing cleavage is also observed in the sandy facies around clasts. Pressure solution is obviously the dominant deformation mechanism as shown by buckled veins normal to the cleavage with dissolved hinges or pressure shadows around detrital clasts in sandy facies (Figure 11) and pyrite in siliceous facies. The ribbon rocks bear a faint mesoscopic mineral and crenulation lineation trending $\mathrm{N} 6 \mathrm{OE}$ in the Maizuru area and $\mathrm{N} 8 \mathrm{OE}-\mathrm{N} 110 \mathrm{O}$ in the KamigoriWakasa and Kuga areas (Figures 4 and 5 ). In thin section, stretching is marked by boudinaged and pull-apart clasts. Crystallization of quartz ribbons and pressure shadows is conspicuous along the lineation. Sometimes asymmetric pressure shadows (Figure 11) and discrete shear bands directed eastwards are also observed. The lineation is interpreted as an "a" lineation showing the sense of transport of the hinterland nappe. Such an eastward sense is in agreement with the eastward nappe motion inferred from microstructures in the outer belt (Faure, 1985b) and with the deformations related to the Jurassic orogeny in the Hida zone; see below.

At the scale of the whole inner belt an eastward nappe displacement is rather difficult to explain unless by assuming a two stage deformation with an early ductile eastward motion reworked by a southeastward brittle thrust. As a matter of fact, the present thrust contact is a reworked one, since the whole succession is seldom found except in the Maizuru area. But the age of reworking is unknown. This interpretation is in agreement with the deformation sequence observed in the Maizuru area. There southward verging subhorizontal brittle shear zones cut obliquely the foliation of the ribbon facies and the underlying Tanba pelites. Though the Tanba rock are generally undeformed, in places, especially in the northern windows, a rough cleavage surrounding the clasts in pebbly mudstone underlined by chlorite and sericite is observed. An E-W preferred orientation of pebble and a true stretching marked by pull-apart pebbles is also conspicuous.

The Hida and circum-Hida domains. The Hida zone is the inner most zone of $\mathrm{SW}$ Japan, (Figure 1). It consists of Paleozoic metamorphics and granites 


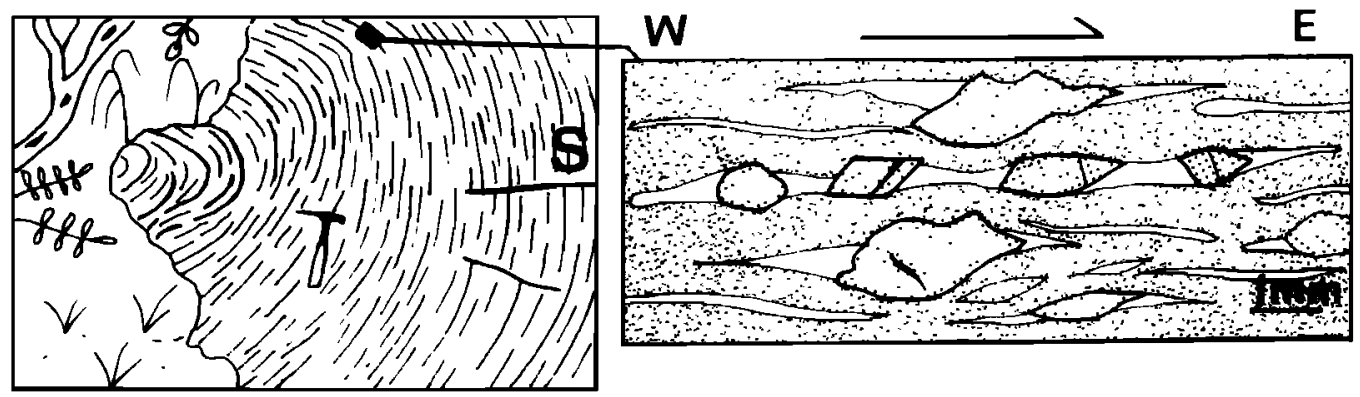

Fig. 11. Thin section of the ribbon rock facies, in section parallel to the lineation and perpendicular to the foliation showing asymmetric quartz pressure shadows around detrital quartz and feldspar, Kuga area.

intruded by Triassic-early Jurassic granites, the Funatsu granites. It is unconformably overlain by Jurassic to Cretaceous shallow water detrital rocks and intruded by late Cretaceous granites. The Jurassic orogeny in this domain will be described in the context of the deformation in the Funatsu granites, the early Jurassic sediments, and looking for reactivaton marks inside the Paleozoic basement.

The early Mesozoic granite: These are granodiorite, diorite, and tonalite mainly distributed along the southern and eastern margin of the Hida zone (Tanaka and Nozawa, 1977; Nozawa, 1979; Figure 8). Their radiometric ages range from $215 \mathrm{Ma}$ to $170 \mathrm{Ma}$ (e.g., Ishizaka and Yamaguchi, 1969; Shibata et al., 1970; Shibata, 1979; Shibata and Nozawa, 1978,1984). The most recent data provide a $\mathrm{Rb}-\mathrm{Sr}$ whole rock isochron age of 189 and $198 \mathrm{Ma}$ for the two main facies. Another facies gives a $\mathrm{Rb}-\mathrm{Sr}$ whole rock age of $297 \mathrm{Ma}$ and a mineral isochron age of $211 \mathrm{Ma}$. Thus a Late Triassic-Early Jurassic age is likely. The Funatsu granites are covered by a late Jurassic conglomerate consisting of reworked pebbles of andesite, ryolite, and acidic tuffs suggesting volcanic activity cogenetic with the granitic plutonism (Nozawa, 1979). The geodynamic significance of the Funatsu magmatism will be discussed with the geodynamic model of the chain.

Along the southern margin of the Hida zone, the granites are transformed into augen gneisses and mylonites (e.g., Kano, 1975, 1983; Isomi and Nozawa, 1957; Nozawa et al., 1975): In the Kamioka area (Figure 8) the foliation trends N6OE to N9OE and dips northward at high angle. Sometimes a subhorizontal stretching lineation trending $\mathrm{N4OE}$ to $\mathrm{N9OE}$ is also present. To the naked eye, the lineation is not always well observed because the mylonitic texture is overprinted and partially removed by K-feldspar porphyroblasts without preferred orientation. Moreover, the flattening component of the deformation is probably important, as shown for instance by the symmetric pressure shadows, conjugate shear zones, and cracks in feldspathic porphyroclasts. However, the study of deformation from the outcrop scale to the microscopic scale in mylonites and orthogneisses (Figure 12) shows rotational criteria in section normal to the foliation and parallel to the lineation, such as asymmetric pressure shadows, oblique pull-apart of the porphyroclasts, and sigmoidal and retort-shaped amphiboles. Such a deformation feature is interpreted as the result of a ductile shear along the strike of the lineation and directed from $W-S W$ to E-NE, in the southern part of the Hida zone (Figure 8 ).

In the eastern part of the Hida zone, the gneissic Funatsu granite trends N-S with a steep westward dip. It is deformed into augen gneiss, mylonite and ultramylonite. The mylonitic foliation bears a subhorizontal lineation. In the augen gneisses asymmetric pressure shadows and shear bands make it possible to infer a dextral shear sense. The deformation history of this area appears rather complex. At first, during the late Permian or early Triassic, the Hida gneisses thrust eastward kyanitesillimanite schists (Hiroi, 1978), developing mylonitic facies with $\mathrm{E}-\mathrm{W}$ trending lineation (Ohta, 1961). Then during late Jurassic the rocks suffered a right lateral shear, which is clearly observed in the early Mesozoic granite. 


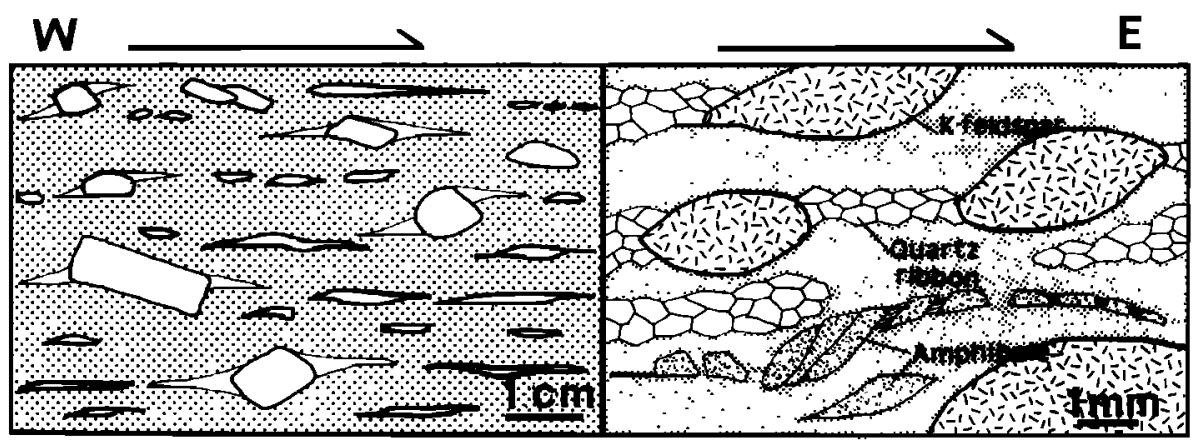

Fig. 12. Deformation of the mylonitic facies of the Funatsu granite in hand specimen, (left) and microscopic scale (right). Sections are perpendicular to the foliation and parallel to the lineation. (a) Asymmetric pressure shadows around the $K$ feldspars, (b) polycrystalline quartz ribbons, (c)retort shape of the amphibole, Kamioka area.

Finally in Cretaceous times or later, the eastern Hida area suffered brittle thrusting similar to the deformation observed in the circum-Hida zone.

As shown in Figure 8 , there is a progressive rotation of the structural trend from $\mathrm{E}-\mathrm{W}$ in the south to $\mathrm{N}-\mathrm{S}$ in the east. This curvature is a late feature related to the left-lateral motion of the Itoigawa-Shizuoka fault during Miocene tectonics such as during the opening of the Japan sea or the collision of the Izu peninsula with the main part of Honshu. Thus, the mylonitization of the Funatsu granite can be attributed to the late Jurassic orogeny. In the whole Hida area a coherent eastward shear is inferred. Given the present subvertical dip of the foliation, it is rather difficult to say if the shear corresponds to a strike-slip movement or if it is related to an initial flat lying thrust steepened by later tectonics.

The Jurassic orogeny in the Hida gneisses: It is very difficult to separate with certainty the deformation structures due to the Jurassic orogeny from older ones into the Hida gneisses or even to prove the existence of a retrograde metamorphism related to the Jurassic deformation. As a clear result of this deformation, there is an isotopic rejuvenation as shown by the Mesozoic radiometric ages around 170-190 Ma obtained from the Paleozoic gneisses (Shibata et al., 1970; Yamaguchi and Yanagi, 1970; Shibata and Nozawa, 1978, Shibata, 1979).

The Jurassic molasse facies: Contrary to the Chugoku domain, Triassic deposits are lacking in the Hida-circum-Hida domain. In this latter domain detrital sedimentation started in the early Jurassic. The lithofacies are quite similar to those of same aged deposits in the Chugoku domain. The early Jurassic Kuruma group is located on the Eastern margin of the circum-Hida zone while, the middle Jurassic to early Cretaceous Tetori group is widespread in the Hida area (Figure 8 ). The early Jurassic rocks are lacustrine, brackish water and shallow marine sandstone and ill-sorted conglomerate bearing Rhaeto-Liassic flora and late Pliensbachian ammonites. In the southern margin of the Hida zone, middle Jurassic clastics unconformably overlie the Hida gneisses and the Funatsu granite. There is an unconformity between the upper Jurassic and the early Cretaceous interpreted as a sedimentary echo of the tectonic movements. The structure is very simple; the Jurassic molasse is folded in upright synclines overturned southward in the southern part and eastward in the eastern part associated with high-angle reverse faults of the same vergence (Nozawa et al., 1975; Uemura and Yokota, 1981).

The circum-Hida zone: The circum-Hida zone marks the boundary between the Hida zone and the Tanba zone. It is largely hidden by Cretaceous granite, lava, and sediments (Figure 8 ). The Omi area, the widest, is the best known (Chihara et al., 1979; Chihara and Komatsu, 1981). It is characterized by Paleozoic sedimentary and metamorphic rocks unconformably covered by the early Jurassic Kuruma group. The main rock facies are (1) early Carboniferous to early late Permian massive limestone. (2) noncalcareous sedimentary rocks. Recently, middle Permian radiolaria have been obtained 
from the siliceous facies (Tazawa et al." 1984). (3) Metamorphic rocks such as biotite pelitic schists, garnet amphibolite, glaucophane-jadeitic schist, and metagabbro. $\mathrm{K}-\mathrm{Ar}$ and $\mathrm{Rb}-\mathrm{Sr}$ measurements on biotite and muscovite provided Paleozoic ages of 310-370, 415, 442 , and 676Ma (Shibata and al., 1970; Shibata and Ito, 1975). (4) Serpentinites (5) Ordovician, Silurian, and Devonian undeformed limestone, shale, and tuff. According to Chihara and Komatsu (1981), the structure of the circum-Hida zone in the Omi area consists of schuppen directed eastward. As a whole, the circum-Hida zone is considered by previous workers as a suture zone between the Hida and the Tanba zones. All the elements of the circum Hida and Tanba zone have been progressively accreted by a continuous subduction from the late Paleozoic to Cretaceous (e.g., Chihara and Komatsu, 1982; Hattori, 1982; Hara, 1982; Mizutani and Hattori, 1983; Hirooka et al., 1983). However, the deformation is obviously polycyclic, since the HP metamorphism is early Paleozoic, the Paleozoic rocks are reworked into the Mesozoic Tetori group, and the Cretaceous formations are folded and cut by thrusts. It should be noted that there is no record of a Mesozoic HP metamorphism related to any subduction. Moreover, Mesozoic ophiolites are lacking, so that the suture hypothesis is not factually supported.

The structural relation between the Tanba zone and the circum-Hida zone is that of a subvertical fault zone. There are striking similitudes in lithology, sedimentology, metamorphism, and stratigraphy between the circum-Hida rocks and the Paleozoic rocks of the Chugoku area. The limestones have the same reefal character; their age ranges from early Carboniferous to middle Permian, as that of the Oga limestones. The metamorphic rocks are comparable to the Sangun metamorphics and the Yakuno ophiolite. One important misfit is the radiometric age, since up to now the Sangun metamorphic rocks are younger (around 240-280 Ma) than the circum-Hida ones. However, early Paleozoic rocks are also recognized among the Sangun metamorphic rocks (Nishimura, 1979). Thus the early Paleozoic ages, though of unclear meaning, also have equivalents in the Sangun-Maizuru zone. Moreover, the resemblance between the Kuruma-Tetori groups and the Jurassic molasse of the Chugoku zone has already been underlined.
Therefore the main difference is structural. The circum Hida zone is squeezed along faults giving rise to schuppen structure. This brittle deformation is unrelated to the Jurassic orogeny, since Cretaceous rocks are involved. However, the present outcrop conditions do not allow any conclusion to be drawn on the Jurassic related deformation. The circum-Hida zone is considered here to be the eastern extension of the Chugoku area dismembered by post-Cretaceous tectonics.

Nevertheless, pre-Cretaceous relationships between the Hida zone and the Circum Hida zone are unresolved. Given that the whole Chugoku domain is a wide nappe overlying the Tanba zone, a large overthrust of the Hida zone upon the circum-Hida-Tanba zone is proposed here

$s$ a working hypothesis.

The inner belt of SW Japan, is a stack of nappes formed during the late Jurassic orogeny. Paleozoic structures such as the Sangun metamorphics, Oga nappe, and Hida zone are seen as "basement nappes". The Tanba zone was deformed for the first time during this orogeny. A two stage motion is inferred for the nappes emplacement. Microtectonic observations suggest that an early pervasive eastward shear was followed by a more superficial south to southeastward thrust. Such a deformation history is in agreement with that which is observed in the outer belt as described below.

\section{AN OUTLINE OF THE GEOLOGY OF THE OUTER BELT}

South of the Median Tectonic Line is the outer belt of SW Japan (Figures 1, 2, and 3) composed of a southern part deformed during the Paleogene Shimanto orogeny and a northern part where the main structure was formed during a late Jurassic orogeny and is covered by Neocomian shallow water deposits. As its litho-stratigraphy, deformation, megastructure, and geodynamic evolution have already been described in some detail (Faure, 1985a, b) only an outline is presented here.

The Jurassic orogeny is responsible for a stack of nappes from top to bottom (Figure 3): the Superficial nappe and the Green Schist nappe. The Superficial nappe consists of a Middle Jurassic olistostrome whose matrix is quite similar to the Tanba olistostrome in age and facies. The olistoliths are PermoCarboniferous limestone, late 
Carboniferous basic volcanoclastics, red shale and chert (resembling the facies of the Oga nappe) and Permo-Triassic radiolarites (similar to the olistoliths found into the Tanba olistostrome). Given these analogies and microtectonic evidence that the superficial nappe emplaced from $\mathrm{N}-\mathrm{NW}$ to $\mathrm{S}-\mathrm{SE}$, it is correlated with the upper unit of the Tanba zone. The olistostrome of the ultra-Tanba zone is also a possible root zone but too little is known about it as it is well identified only in the Maizuru area.

This unmetamorphosed, weakly deformed nappe tectonically overlies a "deep domain" characterized by an HP/MT metamorphism, the famous Sanbagawa metamorphism (e.g., Miyashiro, 1972), and a penetrative ductile deformation. Upon lithological aspects, the deep domain is subdivided into an overlying Green Schist nappe and an underlying sandstone unit, reworked continental detritus, called the Oboke unit. The Green Schist nappe consists of pelitic schists, metaradiolarites and basic rocks both of igneous and sedimentary origin and a few limestones. The major part of the metaradiolarites and basic rocks comprises olistoliths included in the pelitic matrix. Since the uppermost part of the nappe is less metamorphosed, weakly schistosed red shale forming the matrix of a gabbroic olistostrome provided late Jurassic radiolaria (M. Iwasaki et al. unpublished manuscript, 1986). Microtectonic analysis of the deep domain, shows that the ductile deformation is characterized by a conspicuous $E-W$ trending stretching and mineral lineation. The deformation regime is rotational. It was produced by a shear mechanism directed from west to east along the lineation which is thus the transport direction (Faure, 1985b). The schistosity and lineation are refolded by southward overturned folds trending N5OE to N1OOE. This second phase occurred in more superficial levels. It is responsible for the slicing of the Green Schist nappe into two units, so that the higher-grade metamorphic rocks overthrust the lower-grade ones, giving rise to an apparent inverse metamorphism, and also for the thrusting of the superficial nappe upon the "deep domain". The whole pile of nappes and the Neocomian unconformity are folded into upright folds equivalent to the middle Cretaceous upright folds of the inner belt. The sandstone Oboke unit of unknown but likely Mesozoic age is interpreted as having been deposited at the transition between an oceanic area where the elements of the Green Schist nappe were deposited and a continental mass called the South Japan continent. Paleozoic sedimentary, metamorphic, and granitic rocks, unconformably covered by late Triassic-early Jurassic shallow water sediments, outcrop as multikilometerscale lenses in the Kurosegawa zone. This zone is interpreted as the presently outcropping part of the South Japan continent. The southern margin of this continent, called the Sanbosan zone, is made up of a late Jurassic flyschoid sequence reworking Paleozoic rocks derived from the South Japan continent and also late Triassic and late Jurassic limestone, chert, and basic volcanoclastite of unkown origin. The Sanbosan zone is followed southward by Cretaceous and Paleogene turbidites, belonging to the Shimanto zone. The main deformation of the Sanbosan-Shimanto basin occurred in Eocene and Miocene times during the Shimanto orogeny, nevertheless, a preAlbian deformation is likely by comparison with equivalent units in the North Kitakami massif (Figure 1) but has lot yet been recognized.

The mechanism of genesis of the Jurassic orogeny in the outer belt of $\mathrm{SW}$ Japan has been explained by the oblique subduction of an oceanic domain followed by the continental subduction of the South Japan continent and the related thrusting of the oceanic-derived Green Schist nappe (Faure and Charvet, 1984; Faure, 1985a, b). However, it is necessary to replace this with a wider model accounting for both the outer and inner belts. Before that, the geological relationships between the two belts have to be examined.

THE LINK BETWEEN THE TWO BELTS: THE RYOKE ZONE

\section{General Presentation}

The Ryoke zone is important as it forms the junction between the inner and the outer belts. However, its structure has been formed by Cretaceous and younger tectonics. Overlain by Maestrichtian turbidites, called the Izumi group, the Ryoke zone forms a granitogneissic ridge. In agreement with previous works (e.g., Nureki, 1960; Okamura, 1960; Suwa, 1973; 
Ono, 1969; Kutsukake, 1980) the constitutive elements of the Ryoke zone are, from youngest to oldest,

1. Late Cretaceous granites belonging to the Late Cretaceous-Paleogene magmatism widespread into the inner belt. They are undeformed except sometimes along their margins, and are intrusive into element 2.

2. Acidic to intermediate volcanoclastic rocks. They petrographically resemble the undeformed pyroclastic deposits overlying the Tanba zone. Thus their age is assumed to be the same, around $110 \mathrm{Ma}$ (Seki, 1978). Moreover, they are deformed by a subvertical cleavage.

3. The metamorphic complex: the Ryoke zone sensu stricto is divided into the Ryoke metamorphic rocks and the older granites. It is established that the initial facies of the Ryoke metamorphic rocks have the same facies as the Tanba rocks (Nureki, 1960; Kano, 1978; Kutsukake, 1980). Metaradiolarite, marble and sandstone olistoliths are included in a pelitic or sandy mudstone matrix. Therefore a late Jurassic age for the initial sediments is likely. The sedimentary features have been erased out by an HT metamorphism (Miyashiro, 1972; Suwa, 1973). The metamorphic grade increases from north to south from biotite schist through andalusitecordierite and to sillimanite schist. Migmatite and granite are the end member of this metamorphic sequence. Thus the so called older granites are formed by anatexis of the Tanba sediments. Owing to a late Cretaceous resetting, the age of the HT metamorphism is not precisely known. It occurred before the AptianAlbian acidic volcanism and after the late Jurassic sedimentation in the Tanba zone. An early Cretaceous age is therefore likely. The Ryoke metamorphic rocks and the migmatites are folded by upright $E-W$ trending folds. The foliation bears an $\mathrm{E}-\mathrm{W}$ mineral lineation (Figure 4, Nureki, 1960; Okamura, 1960) but it is very difficult to show the evidence for a Jurassic deformation.

\section{The Pre-Ryoke Concept}

Some exposures of the older granites are described as orthogneisses (Kojima and Okamura, 1968; Nureki, 1979) interpreted as a Paleozoic or Precambrian substratum of the Ryoke metamorphic rocks, called the pre-Ryoke basement.
However, arguments are scarce, since the othoderived character of gneisses is not certain. All the radiometric ages are reset by the Cretaceous granites, and all the structural arguments reviewed by Yoshida (1981) are diputable. In the same way, granitic conglomerate in the Ryoke metamorphic rocks does not imply an unconformity, since there are also interstratified conglomerate bearing metamorphic rocks in the Tanba olistostrome. Evidence for a sialic basement underlying both the Ryoke and Tanba zones is brought by the xenoliths found in the Tertiary volcanoes. According to petrologic studies (Nureki and Murakami, 1979; Asami and Asami, 1982), they are of granite, granulite, and amphibolite whose minerals are not in equilibrium with the Ryoke metamorphism. It is evident that they were formed deeper in a continental crust. Nevertheless, it is not certain that they are pre-Jurassic. According to Ishizaka et al. (1984), their radiometric age ranges between 100 and $200 \mathrm{Ma}$, but a late resetting also cannot be discarded. Finally, an underlying sialic basement is necessary to provide the enormous volume of acidic magma produced in late Cretaceous and Paleogene. However, it could be either a the pre-orogenic basement of the Tanba-Ryoke zone or a continental block tectonically emplaced during the Jurassic orogeny as proposed in our model.

The Median Tectonic Line and the paleo-Ryoke concept

The present boundary between the inner and the outer belts is the Median Tectonic Line (MTL). Generally, the fault zone is marked by gouge and cataclastic rocks lying between the Green Schist nappe to the south and the Maestrichtian Izumi sandstone or the Cretaceous granites to the north. The oldest known motion along the fault corresponds to a left lateral strike slip leading to the mylonitization of the Ryoke metamorphic rocks. Nevertheless, the deformation is posterior to the Jurassic orogeny (Hara et al., 1980; Ichikawa, 1980).

It is worth to note that the HT Ryoke metamorphism, though younger is undetected into the Green Schist nappe. There is a deep structural and metamorphic gap between the Ryoke metamorphic rocks and the Green Schist nappe. The Ryoke metamorphic rocks form 
an antiform whose southern limb is cut by the MTL. The metamorphic isograds both in the Green Schist nappe and the Ryoke rocks are oblikely cut by the MTL. Therefore it is suggested that during the motion of the MTL some intermediate fragments called the "missing Ryoke" (Miyashiro, 1972; Kojima, 1973; Nureki and Okamura, 1977) have disappeared.

Moreover, in the whole SW Japan there is no detrital material from the Green Schist nappe, though granite, Paleozoic sediments, and Ryoke metamorphic rocks are abundantly reworked into the Maestrichtian molasse. Thus it is assumed that the Green Schist nappe was overlain by a part of the Ryoke zone, called the paleo-Ryoke (Yabe, 1963; Miyashiro, 1972, Kojima, 1973; Nureki and Okamura, 1977; Ichikawa, 1980). It was lccated south of the MTL and has been eroded off between late Cretaceous and Paleogene times to produce the Izumi molasse. The concept of a paleo-Ryoke is independent of that for a pre-Ryoke. The former could be formed either by a pr-eRyoke basement and its sedimentary cover or only by this last part, i.e., the Tanba rocks and the Superficial nappe.

Thus in conclusion, the Ryoke zone represents the southern part of the Tanba zone, deeply perturbed by a thermal metamorphism. The Ryoke metamorphism and the deformation related to the MTL correspond to a late feature overprinted upon the Jurassic chain. However, it is likely that some segments between the Ryoke zone and the Green Schist nappe are presently missing.

\section{THE MESOZOIC PALEOGEOGRAPHY AND GEODYNAMICS}

\section{Collage versus linkage}

Since the MTL presently represents an important gap, two kinds of relationships between the inner and outer belts of $\mathrm{SW}$ Japan can be imagined. One assumes that paleogeographic and tectonic relationships never existed between them before middle Cretaceous. Each belt

independantly developed its late Jurassic structure and metamorphism in remote areas. Afterwards, during Middle to Late Cretaceous times they were placed in close contact with each other by left lateral motion of the MTL. Since that time, inner and outer belts have behaved as a single unit whose evolution is explained by subduction on the south side of the South Japan continent, responsible for the Shimanto orogeny. As the structural features of the outer belt can be followed from Okinawa to eastern Hokkaido, along more than $2500 \mathrm{~km}$, a considerable displacement is necessary in such a hypothesis. Such a model is a kind of "collage," as defined by Helvig (1974) and is largely used to explain the structure of the western North America Cordillera (e.g. Coney et al, 1981; Jones et al., 1983; Monger, 1984).

However, in the case of SW Japan, several similarities between the two belts should be emphasized. First, the main deformation occurred at the same time in the late Jurassic, second, the same deformation style and history occurred at the same time. The nappe motion is characterized everywhere by an early eastward displacement followed by a south-southeastward one. Third, matrix and olistoliths of the Superficial nappe of the outer belt are identical to the Tanba olistostrome and the Paleozoic rocks of the Chugoku area, respectively. We assume that parts of the Paleozoic rocks at first redeposited into the Tanba basin in middle to early late Jurassic times, then these were thrusted together with the Tanba sediments above the Green Schist nappe in late Jurassic-early Cretaceous times. Hence a model linking the evolution of the two belts is developed in the following.

\section{The Late Triassic-Early Jurassic}

It is now well established that the Japan sea opened in the Miocene (e.g., Otofuji and Matsuda, 1984; Lallemand and Jolivet, 1986) detaching the Japanese islands from Asia. The Triassic-Jurassic molasse facies of the hinterland is similar to the continental terrigenous deposits of Manchuria (Wang and Sun, 1983), Shikhote Alin (Kimura, 1973; Gnibidenko et al., 1977), Korea (Reedman and Um, 1975; Yu, 1983) and bears the same Rhaetic-Liassic flora (Kimura 1980). In South Korea the late Jurassic Daebo orogeny (Reedman and Um 1975, Lee, 1980) is recognized. As in the hinterland of $\mathrm{SW}$ Japan the deformation is weak, only marked by brittle high angle faults and open folds. The early Mesozoic Funatsu granite has an equivalent in North Korea (Lee, 1980) but it cannot be compared with the South Korean Daebo granite, 


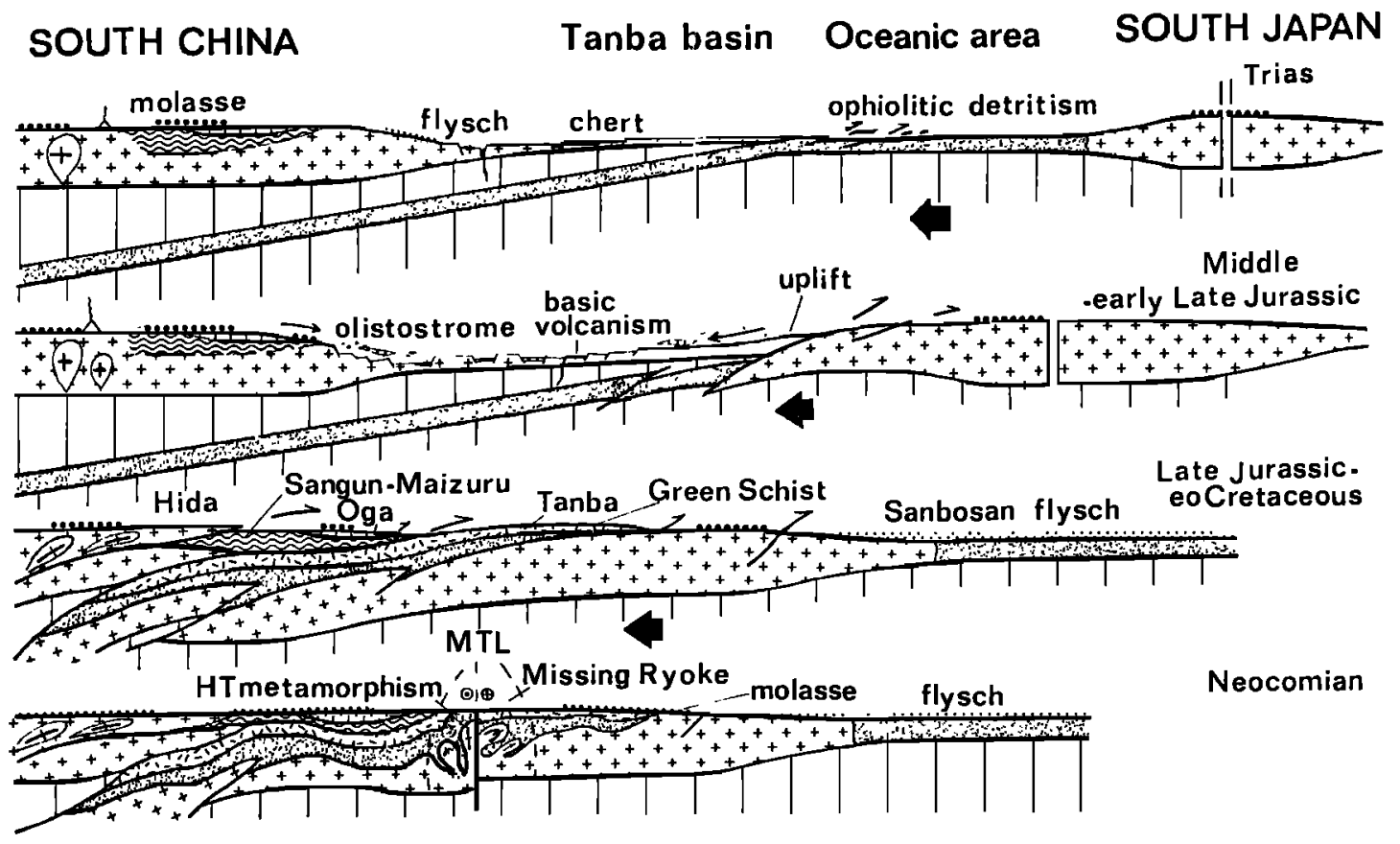

Fig.13. Geodynamic model for the Jurassic orogeny of SW Japan, emphasizing the nappe structures and the continental subduction of the South Japan continent. The detailed structure of the Green Schist nappe and the Tanba zone is not represented.

since they differ in age, petrology, and geochemistry, (e.g. Iiyama and Fonteilles, 1981; Ishihara et al., 1981). Thus the hinterland of SW Japan represents a part of a pre-Triassic northern continent. The South China block, which includes the southern part of Korea is the most likely.

The Tanba zone remains the most problematic element of the inner belt. Late Triassic-Early Jurassic normal and possibly strike-slip faulting gave rise to a kind of horst and graben pattern. In the proximal parts of the Tanba basin flyschoid deposition took place, while in the distal parts siliceous sedimentation occurred (Figure 13). Since the amount of Mesozoic neoformed oceanic crust is small the distension did not produce a large oceanization. In our model the Tanba zone is seen as a forearc basin floored by the thinned continental crust of the South China block with some limited oceanic parts and filled by continental derived sediments. A remote source for the Permian radiolarian cherts is not necessary; it may represent in situ reworked rocks from the substratum of the Tanba basin. This interpretation is in agreement with sedimentology but does not fit with paleomagnetic data (Hirooka et al., 1983, Mizutani and Hattori, 1983; Sasajima, 1984) which indicate that during the Jurassic the hinterland of $\mathrm{SW}$ Japan was at the same latitude as at present and that the Tanba zone was at subequatorial latitudes. However, the data for the Hida zone are derived from the Funatsu granite, and for the Tanba zone, from Paleozoic olistoliths and shaly matrix of the olistostrome, so that comparison is difficult, not to mention the correction difficulties for the deformed Jurassic granite.

South of the Tanba basin there was an oceanic domain subducting under the Tanba basin in which radiolarite, limestone, and pelite were deposited together with some reworked ophiolitic rocks. They form the material of the Green Schist nappe. The cause of the ophiolitic reworking is disputed; spreading ridge, trough, sea mount, transform fault, or intraoceanic tectonic wedge related to the subduction are suitable environments for providing a sufficient topographic gradient necessary for this kind of reworking.

The Funatsu and North Korean granites 
are interpreted as one of the effects of the subduction. The granite, acidic and calcalkaline lava reworked into the Tanba sediments, may also have been derived from rocks formed by this subduction. This plate also incorporates the South Japan continent, upon which shallow water detrital rocks were deposited. On the outer side, chert, limestone and basic volcanoclastic rocks accumulated in the Sanbosan zone.

There is the possibility that since this time, deformation and metamorphism occurred in the oceanic domain but the main deformation was induced by the subduction of the South Japan continent.

The Middle Jurassic-Early Late Jurassic

As the molasse sedimentation continued in the hinterland, the sedimentation became more and more chaotic in the Tanba basin, prograding from the hinterland. Olistostromes were formed in the upper unit and in the ultra-Tanba zone, while in the lower unit, i.e., the most distal one, sedimentation of cherts was still possible. The origin of the olistostrome is tentatively suggested to have been related to a progressive uplift of the hinterland due to subduction. Southward the South Japan continent entered the subduction zone. As a consequence, the edge of the Tanba basin was uplifted; this may be the origin of the southward gravity sliding deposits of the Mino area. At depth the HP/MT metamorphism and early tectonics may have begun in this time. The future Green Schist nappe suffered its early HP metamorphism recorded into the metagabbro and eclogites.

\section{The Late Jurassic-Early Cretaceous}

At that time the main nappe tectonics occurred. The basic mechanism for orogeny is the convergence between the South China and the South Japan continents. The convergence at first accommodated by the oceanic subduction of the Green Schist sediments was followed by the subduction of the continent itself. The subduction stopped, whether owing to global reasons inducing a change in relative plate motion, for instance, from pure shortening to strike-slip motion, or only for regional mechanical reasons; for instance, when enough continental crust was subducted, the subduction was choked owing to the buoyancy of the continental crust. The collision gave rise to large nappes pilled up upon the South Japan continent. From bottom to top are the Green Schist nappes, the Tanba and Superficial nappes, the ultra-Tanba zone, the hinterland nappe where the Paleozoic thrusts were reused, and the uppermost Hida zone. At depth the crust of the hinterland is probably sliced in the same way that the Austro-Alpine nappes have been in the Alps (e.g., Aubouin 1981). The Tanba nappes are assumed to lie tectonically upon the extension of the Green Schist nappes, themselves obducted upon the South Japan continent. In the Sanbosan zone the flysch deposit is seen as the sedimentary echo of the collision. As stated above, microtectonics show that nappe displacement occurred, in the early stages, with a dominant eastward component parallel to the trend of the chain. The early E-W motion is best recognized in the Green Schist nappes, but eastward directed deformation is also clear into the Funatsu granite and the ultra-Tanba zone. As in other orogenic zones, nappe displacement shown by the lineation and asymmetric criteria is assumed to be close to the direction of convergence (e.g., Escher and Watterson, 1974; Mattauer ,1975; Mattauer et al., 1981; Malavielle et al.,1984). Therefore the convergence between the South China and South Japan continents is assumed to have been one of oblique subduction.

\section{The Neocomian}

The orogeny was completed in the middle Cretaceous when the MTL divided the chain into two belts. The nappe contacts were covered by the continental formations and by the acidic volcanism in the inner belt, and in the outer belt, by shallow water deposits. The left lateral displacement along the MTL induces en echelon upright folds (Hara et al., 1980). At that time a HT Ryoke metamorphism developed whose geodynamic causes are not well understood. One could argue that the crustal thickening due to the collision was responsible for the HT metamorphism. However, this explanation alone is not sufficient, since the Ryoke metamorphism forms a well-delimited linear zone. It is likely that it was related to the ductile deformation along the MTL. A kind of large-scale shear heating, enhanced by the still hot, 
underlying South Japan continental crust, is proposed here as a working hypothesis.

A new subduction south of the Sanbosan zone began from middle Cretaceous times. Its evolution led to the Shimanto orogeny, and the huge late CretaceousPaleogene magmatism widespread in Japan, as on the eastern margin of Asia from Southeast China to Eastern Siberia. In our model the origin of the calcalkaline magma is located in the postorogenic basement of the Tanba zone, that is to say, a part of the South Japan continent.

\section{CONCLUSION}

Two sets of models aim to account for the geology of Japan. The "Pacific type orogeny" proposed for the Cenozoic tectonics is extended to older orogens (e.g., Miyashiro, 1972; Kimura, 1973; Uyeda and Miyashiro, 1974; Chihara and Komatsu, 1981; Hara, 1982; Hada et al., 1982; Hirooka et al., 1983; Mizutani et al., 1983). It assumes that the constitutive units of Japan were progressively accreted onto Asia by the continuous subduction of an oceanic plate since Paleozoic. The second group consists of collisional models/Ogawa, 1978; Ono, 1980; Ichikawa, 1981, Charvet et al., 1983; Sasajima, 1984; Faure and Charvet, 1984; Faure, 1985a). Depending on the authors, two or three of the Hida, pre-Ryoke, and Kurosegawa blocks are involved. However, the precise geological data are seldom integrated into the scheme.

The nappe structure and HP/MT metamorphism of SW Japan related to the late Jurassic orogeny fits better to a model where orogeny is driven by the continental subduction of the South Japan mass than to with an oceanic subduction driven model. Basically, the late Jurassic orogeny in SW Japan is responsible for a stack of nappes with hundred-kilometer displacements. From top to bottom there is (1) a "basement nappes" complex formed by the hinterland: Hida and Chugoku areas, (2) a forearcderived nappe complex with the ultraTanba zone, and the Tanba and Superficial nappes, and (3) an oceanic derived nappe complex with the Green Schist nappes. The whole pile lies upon the South Japan continent.

Such a model is similar to the collisional models exemplified by the Western Alps and the Himalayas. However, several peculiar features of SW Japan must be emphasized here:

1. There are no ophiolites in the sense of large masses of basic-ultrabasic associations. Even inside the Green Schist nappe which can be regarded as a kind of ophiolitic nappe, the magmatic part is underrepresented and always reworked into sediments before the deformation.

2. The famous HP/MT Sanbagawa metamorphism is in fact an atypical one, since true high pressure assemblages are absent.

3. Moreover, tectonic analysis reveals the importance of early longitudinal displacements, related to nappe tectonics as soon as in the synmetamorphic deformation stage. For that reason, pure convergence has to be coupled with strike slip into an oblique collision model. This feature is probably the most original character of the Jurassic orogen of SW Japan.

Acknowledgements. J. Aubouin, J.P. Cadet, J.T.Iiyama, M. Iwasaki, K. Ichikawa, and Lee Byong Joo are acknowledged for enlighting discussions and help during the field and laboratory works. An anonymous reviewer helped greatly to improve the English. The authors wish to thank the University of Tokyo, the University of Tokushima, and the Osaka City University for providing material facilities for M.F. and M.C. The work expenses were supplied by grants from the Ministry of Education of Japan for M.F., from the Ministère des Relations Extérieures for M.C., and from the KAIKO project for J.C.

\section{REFERENCES}

Adachi, M., Permian intraformational conglomerate at Kamiaso, Gifu prefecture, Central Japan, J. Geol. Soc. Jpn, 77, 471-482, 1971.

Adachi, M., and S., Kojima, Geology of the Hikagedaira area, East of Takayama, Gifu prefecture, Central Japan, J. Earth Sci. Nagoya Univ., 31, 37-67, 1983.

Asami, M., and S. Asami, Granulite xenoliths in andesites from Amagiriyana, Kagawa Prefecture, Mem. Geol. Soc. Jpn, 21, 151-161,1982. Aubouin, J., About mountain building, Geol. Soc. China, Mem. 4, 33-53, 1981. 
Caridroit, M., J. Charvet, and K. Ichikawa, Une nouvelle unité dans les zones internes du Japon du SW. Son importance dans les structures en nappes d'après l'exemple de la région deMaizuru, C. R. Séances Acad. Sci. Sér. C, 299, 1215-1220, 1984.

Caridroit,M., J.Charvet, and $\mathrm{K}$. Ichikawa, The Ultra-Tanba zone, a new unit in the inner zones of SW Japan, its importance in the nappe structures after the example of the Maizuru area, Earth Sci. Tokyo, 39, 210-219, 1985.

Charvet, J., J.P. Cadet, J. Aubouin, and M. Faure, Sur l'importance de la tectonique au Japon Central et Méridional, C. R. Séances Acad. Sci. Sér. C, 296, 1279-1286, 1983.

Chihara, K., and M. Komatsu, Tectonics of the Hida and Joetsu Tectonic Belts, in Symposium on Tectonics of Paired Metamorphic Belts, edited by I. Hara, pp. 135-142, Tanishi Print, Hiroshima, Japan, 1981.

Chihara, K., M. Komatsu, T. Uemura, Y. Hasegawa, S. Shiraishi, T. Yoshimura, and M. Nakamizu, Geology and tectonics of the Omi-Renge and Joetsu belts(5), Geology of the Omi-Renge tectonic belt, Sci. Rep. Niigata Univ., 5, 1-61, 1979.

Coney, P. J., D. L., Jones, and J. W. H. Monger, Cordilleran suspect terranes, Nature, 288, 329-323, 1981.

Escher, A., and J. Watterson, Stretching fabrics, folds and crustal shortening, Tectonophysics, 39, 3-24, 1974.

Faure, M., The Pre-Cretaceous structure of the Outer belt of Southwest Japan, Tectonophysics, 113, 139-162, 1985a.

Faure, M., Microtectonic evidence for eastward ductile shear in the Jurassic orogen of SW Japan, J.Struct. Geol.,7, 175-186, $1985 \mathrm{~b}$.

Faure, M., and M. Caridroit, Tectoniques tangentielles superposées dans les zones "internes" du Japon SW, d'après l'exemple de la région de Kamigori, C.R. Séances Acad. Sci. Sér.C, 297, $165-170,1983$.

Faure, M., and J. Charvet, Mesozoic nappe structure in SW Japan from the example of Eastern Shikoku and Kinki areas, Sci. Geol. Bull., 37, 51-63, Strasbourg, 1984.

Gnibidenko, H. S., V. V. Argentov, and S. V. Potapyev, Geology and deep structure in Primorye, Southwestern Sikhote-Alin, USSR, Pac. Geol., 12, 71-98, 1977.

Guidi, A., J. Charvet, T. Sato, and S. Takizawa, Les structures tangentielles
anté-Cretacé dans les Monts Kanto: Résultats préliminaires, C. R. Séances Acad. Sci. Sér. C, 298, 307-312, 1984.

Hada, S., T. Suzuki, K. Okano, and S. Kimura, Crustal section based on the geological and geophysical features in the outer zone of Southwest Japan, Mem., Geol. Soc. Jpn.,21, 197-211, 1982.

Hara, I., Evolutional processes of paired metamorphic belts, Mem. Geol. Soc. Jpn., 21, 71-89, 1982 .

Hara, I., K. Shyoji, Y. Sakurai, S. Yokoyama, and $\mathrm{K}$. Hide, Origin of the Median Tectonic Line and its initial shape, Mem. Geol. Soc. Jpn., 18, 71-89, 1980.

Hase, A., Paleozoic formations in Hiroshima prefecture, in Explanatory text of the geological map of Hiroshima prefecture, pp. 31-59, Hiroshima Pref., 1964.

Hattori, I., The Mesozoic evolution of the Mino terrane, Central Japan: A geologic and paleomagnetic synthesis, Tectonophysics, 57, 313-340, 1982.

Hattori, I., and M. Yoshikawa, Late Triassic to middle Jurassic ages for greenstones within the Mesozoic Nanjo massif of the Mino Terrane, Central Japan, Annals of Kyoiku Gakubu, Fukui Univ., 32, 67-80, 1983.

Hayasaka, Y. and I. Hara, Discovery of Jurassic radiolaria in the Chugoku belt and its structural significance, paper presented at 89th. meeting of the Geol. Soc. Jpn., Niigata, 1982 .

Hayasaka, Y., Y. Isozaki, and I. Hara, Discovery of Jurassic radiolaria from the Kuga and Kanoashi groups in the Western Chugoku district, Southwest Japan, J. Geol. Soc. Jpn.,89, 527-530, 1983.

Helwig, J., Eugeosynclinal basement and a collage concept of orogenic belts, Soc. Econ. Paleontol. Mineral. Spec. Publ. 19, 359-376, 1974.

Hiroi, Y., Geology of the Unazuki district in the Hida metamorphic terrain, central Japan, J. Geol. Soc. Jpn., 84, 521-530, 1978.

Hirooka, K., T. Nakajima, H. Sakai, T. Date, K. Nittamachi, and I. Hattori, Accretion tectonics inferred from paleomagnetic measurements of Paleozoic and Mesozoic rocks in Japan, in Accretion Tectonics in the circumPacific region, edited by M. Hashimoto and S. Uyeda, pp. 179-194, Terrapub, Tokyo, 1983.

Ichikawa, K., Geohistory of the Median 
Tectonic Line of South-west Japan, Mem. Geol. Soc. Jpn., 18, 187-212, 1980.

Ichikawa, K., Closure of the Jurassic sea in and around the Ryoke-Kurosegawa region, paper presented at Symposium on Tectonics of Paired Metamorphic Belts, Hiroshima, 1981.

Iijima, A., Y. Kakuwa, Y. Yamazaki, and Y. Yanagimoto, Shallow sea, organic origin of the Triassic bedded cherts in Central Japan, J. Fac. Sci. Univ. Tokyo, 19, 369-400, 1978.

Iiyama, J.T., and M. Fonteilles, Mesozoic granitic rocks of Southern Korea reviewed from major constituents and petrography, Min. geol., 31, 281295, 1981.

Imoto, N,. and M. Fukutomi, Genesis of bedded cherts in the Tanba belt, Southwest Japan, Assoc. Geol. Collab. Jpn., Monogr. 19, 35-42, 1975.

Imoto, N., D. Shimizu, and Tanba Belt Research Group, Reexamination of the stratigraphy of the Paleozoic-Mesozoic system in the Tanba belt, $\mathrm{J}$. Assoc. Struct. Geol., 25, 25-31, 1981 .

Ishiga, H., Two suites of stratigraphic succession within the Tanba Group in the Western part of the Tanba Belt, SW Japan, J. Geol. Soc. Jpn., 89, 443$454,1983$.

Ishihara, S., D. S. Lee, and S. Y. Kim, Comparative study of Mesozoic granitoids and related W-Mo mineralization in Southern Korea and Southwest Japan, Min. geol., 31, 311$320,1981$.

Ishizaka, K., and M. Yamaguchi, U-Th-Pb ages of sphene and zircon from the Hida metamorphic terrain, Japan, Earth Planet. Sci. Lett., 6, 179-185, 1969.

Ishizaka, K., T. Yanagi, and N. Murakami, $\mathrm{Sr}$ isotopic study of mafic inclusions from Utajima, Southwest Japan, Geochem. J., 18, 203-208, 1984.

Isomi, $H_{.}$, and $T$. Nozawa, Geological map of Funatsu, and its explanatory text, 1/50000, Geol. Surv. Jpn., Tsukuba, 1957.

Isozaki, Y., and T. Matsuda, Age of the Tanba Group along the Hozugawa "anticline", Western hills of Kyoto, Southwest Japan, J. Geosci. Osaka City Univ. 23, 115-134, 1980.

Jones, D., F.G. Howell, P. J. Coney, and J. W. H. Monger, Recognition, character and analysis of tectonostratigraphic terranes in Western North America, in Accretion Tectonics in circum-Pacific Region edited by M. Hashimoto and $S$. Uyeda, pp. 21-35, Terrapub, Tokyo, 1983.
Kano, K., Stratigraphy and structure of the Ryoke metamorphic rocks in Aichi prefecture, Central Japan, J., Geol. Soc. Jpn, 84, 445-458,1978.

Kano, K., Giant deckenpacket and olistostrome in the Eastern Mino district, Central Japan, J. Fac. Sci. Univ. Tokyo, II, 20, 31-59, 1979.

Kano, T., Geological study of the Hida metamorphic belt in the eastern part of Toyama prefecture, central Japan, J. Geol. Soc. Jpn., 81, 533- 546,1975.

Kano, T., Origin of augen gneisses and related mylonitic rocks in the eastern part of the Hida metamorphic region, Central Japan, J. Geol. Soc. Jpn., 89, 375-393, 1983.

Kawai, M., Geological map of Tsuyamatobu, and its explanatory text, 1/50000, Geol. Surv. Jpn., Tsukuba, 1958.

Kimura, T., The old Inner Arc of Japan and its deformation, in The Western Pacific Island Arcs, Marginal seas, Geochemistry, edited by P. J. Coleman, pp. 255-273, University of Western Australia Press, Nedlands, 1973.

Kimura, T., The present status of the Mesozoic floras of Japan, in Prof. S. Kanno Memorial Volume, edited by S. Kanno, pp.379-413, Akita University, 1980.

Kimura, T., S., Yoshida, and F., Toyohara, Paleogeography and Earth movements of Japan in the Late Permian to early Jurassic Sanbosan stage, J. Fac. Sci. Univ. Tokyo, 19, 149-177, 1975.

Klimetz, M. P., Speculations on the Mezosoic plate tectonic evolution of Eastern China, Tectonics, 2, 139-166, 1983.

Kobayashi, T., The Sakawa orogenic cycle and its bearing on the origin of the Japanese islands, J. Fac. Sci. Univ. Tokyo, 5, 219-578, 1941 .

Kojima, G., Geologic segments lost at the Median Tectonic Line, in The Median Tectonic Line, edited by $\bar{R}$. Sugimura, pp. 253-261, Tokai Univ. Press, Tokyo, 1973.

Kojima, G., and K., Okimura, On the Kitaoshima granite-gneiss complex, J. Sci. Hiroshima Univ. ser. C, 5, 295306, 1968.

Kutsukake, T., Nature of the Ryoke regional metamorphism and plutonism, Mem. Fac. Sci. Kyoto Univ. ser. Geol. Mine. 47, 49-59, 1980.

Lallemand, S., and L. Jolivet, The Japan sea: A pull apart basin?, Earth Planet. Sci. Lett. 76, 375-389, 1986. 
Lee, S., Geology and tectonics of the Korean peninsula, in Geology of the Globe, edited by A. Miyashiro, pp. 355-384, Iwanami Shoten, Tokyo,1980.

Malavieille, J., R. Lacassin, and M. Mattauer, Signification tectonique des linéations d'allongement dans les Alpes Occidentales, Bull. Soc. Geol. Fr. , 5, 897-903, 1984 .

Matsumoto, R. and A. Iijima, Chemical sedimentology of some Permo-Jurassic and Tertiary bedded cherts in Central Honshu, Japan, in Developments in sedimentology, 36 , Siliceous deposits in the Pacific region, edited by $A$. Iijima, J. R. Hein and R. Siever, pp.175-191, Terrapub, Tokyo, 1983.

Mattauer, M., Sur le mécanisme de formation de la schistosité dans I'Himalaya, Earth Planet. Sci. Lett., 28, 144-154, 1975.

Mattauer, M., M. Faure, and J. Malavieille, Transverse lineation and large scale structures related to alpine obduction in Corsica, J. Struct. Geol. , 3, 401-409, 1981.

Mitsuno, C., and N. Omori, Geological map of Susai, and its explanatory text, 1/50000, Geol. Surv. Jpn., Tsukuba, 1964.

Miyashiro, A., Metamorphism and related magmatism in plate tectonics, Am. J. Sci., 272, 629-656, 1972.

Mizutani, S., and I. Hattori, Hida and Mino: Tectonostratigraphic Terranes in Central Japan, in Accretion Tectonics in circum-Pacific region, edited by $M$. Hashimoto and S. Uyeda, pp.169-178, Terrapub, Tokyo, 1983.

Mizutani, S., I. Hattori, M. Adachi, K. Wakita, Y. Okamura, S. Kido, I. Kawaguchi, and S. Kojima, Jurassic formations in the Mino area, Central Japan, Proc. Jpn. Acad., Ser. B, 57, 194-199, 1981.

Monger, J. W. H., Cordilleran tectonics: A Canadian perspective, Bull. Soc. Geol. Fr., 26, 1984.

Nakazawa, K., and T. Shiki, Geology of the Miharaiyama, Yabu gun, Hyogo prefecture, Japan, with special reference to the Triassic Miharaiyama group, J. Geol. Soc. Jpn., 60, 192-201, 1954.

Nishida, M., M. Adachi, and N. Kondo, Fossil fragments of petrified wood from pre-Tertiary formations in the northern area of Inuyama city, Aichi prefecture, and their bearing on the geology, J. Jpn. Bot., 49, 265-272, 1974.
Nishimura, Y., Metamorphic rocks of $300-400 \mathrm{Ma}$ ages found in the Inner zone of Southwest Japan, in The Basement of the Japanese Islands, edited by $H$. Kano, pp. 201-216, Akita University, Akita, Japan, 1979.

Nishimura, Y., Tectonics of the Sangun belt, paper presented at Symposium on Tectonics of Paired Metamorphic Belts, Hiroshima, 1981.

Nishimura, Y., E. Nakamura, and I. Hara, $\mathrm{K}-\mathrm{Ar}$ ages of Sangun metamorphic rocks in Yamaguchi prefecture and their geologic significance, J. Jpn. Assoc. Mineral. Petrol. Econ. Geol. 78, 11$20,1983$.

Nozawa, T., K. Kawada, and M. Kawai, Geological map of Hida-Furukawa, and its explanatory text, 1/50000, Geol. Surv. Jpn., Tsukuba, 1975.

Nozawa, T., Some problems on Funatsu granitic rocks, in The basement of the Japanese Islands, edited by $\mathrm{H}$. Kano, pp. 101-117, Akita University, Akita, Japan, 1979.

Nozawa, T., K. Kawada, and M. Kawai, Geological map of Hida-Furukawa, and its explanatory text, 1/50000, Geol. Surv. Jpn., Tsukuba, 1975.

Nureki, T., Structural investigations of the Ryoke metamorphic rocks of the area between Iwakuni and Yanai, SW Japan, J. Sci. Hiroshima Univ. Ser. C, 2, 109-127, 1960.

Nureki, T., On the pre-Ryoke basement rocks, in The basement of the Japanese Islands, edited by H. Kano, pp. 183199, Akita University, Akita, Japan, 1979.

Nureki, T and N. Murakami, A general survey of xenoliths found in the Cenozoic volcanic rocks in West Japan, in The basement of the Japanese islands, edited by H. Kano, pp. 217232, Akita University, Akita, Japan, 1979.

Nureki, T., and Y. Okamura, Tectonic relations of the Sanbagawa metamorphic belt to the Ryoke metamorphic belt in Southwest Japan, in The Sanbagawa belt, edited by $\mathrm{K}$. Hide, pp. 391-410, Hiroshima University Press, Hiroshima, 1977.

Ogawa, Y., Structural characteristics and tectonisms around the microcontinent in the outer margin of the PaleozoicMesozoic Geosyncline of Japan, Tectonophysics, 47, 295-310, 1978. ohta, Y., The plutonics and metamorphics in the northeastern area of the Hida 
Metamorphic zone, II: Geological Structure, J. Geol. Soc. Jpn., 67, 676-687, 1961 .

Okamura, Y., Structural and petrological studies on the Ryoke gneiss and granodiorite, complex of the Yanai district, Southwest Japan, J. Sci. Hiroshima Univ. Ser. Geol. Mineral., 3, 143-213, 1960.

Ono, A., Zoning of the metamorphic rocks in the Takato-Shiojiri area, Nagano prefecture, J. Geol. Soc. Jpn., 75, $521-536,1, \overline{1969}$.

Ono, A., A model for the formation of the Ryoke-Sanbagawa paired metamorphic belts, J. Jpn. Assoc. Mineral. Petrol. Econ. Geol., 75, 31-37, 1980.

oto, S., Geological structure of the Oga and Atetsu areas, M.S. thesis, Univ. of Tokyo, 1984.

Otofuji, Y., and T. Matsuda, Timing of rotational motion of Southwest Japan inferred from paleomagnetism, Earth Planet. Sci. Lett.; 70, 373-382, 1984.

Reedman, A. J., and S. M. Um, 139 pp. The Geology of Korea, Geological and Mineral Institute of Korea, Seoul, 1975.

Sakamoto, H., On the base and sedimentary cycles of the Mine Group, Geol. Rep. Kyushu Univ., 10, 25-30, 1969.

Sasajima, S., The Growth of Eastern Asia inferred from paleomagnetism, in Mobile belts of Asia, edited by K. Fujita, pp.239-256, Kaibundo Press, Osaka, Japan, 1984.

Seki, T., Rb-Sr geochronology and petrogenesis of the late Mesozoic igneous rocks in the inner zone of the southwestern part of Japan, Mem. Fac. Sci. Kyoto Univ., Ser. Geol. Mineral., 45, 71-110, 1978 .

Shibata, K., Geochronology of preSilurian Basement rocks in the Japanese islands with special reference to age determinations on orthoquartzite clasts, in The basement of the Japanese Islands, edited by $\mathrm{H}$. Kano, pp. 625-639, Akita University, Akita Japan, 1979.

Shibata,K., and S. Igi, K-Ar ages from muscovite-quartz schist of the Sangun metamorphic terrain in the Tari District, Tottori prefecture, Japan, Bull. Geol. Surv. Jpn., 20, 707-709, 1969.

Shibata, K., and M.,Ito, Isotopic ages of schists from the Asahidake-Shiroumadake area, Hida mountains, J. Jpn. Assoc. Mineral. Petrol. Econ. Geol., 73, 1-4, 1975.
Shibata, K., and T. Nozawa, K-Ar ages of hornblendes from the Hida metamorphic belt, J. Jpn. Assoc. Mineral. Petrol. Econ. Geol., 73, 137-141,1978.

Shibata, K., and T. Nozawa, Isotopic ages of the Funatsu Granitic Rocks, J. Jpn. Assoc. Mineral. Petrol. Econ. Geol., 79 289-298, 1984.

Shibata, K., T. Nozawa, and R. K. Wanless, Rb-Sr geochronology of the Hida metamorphic belt, Japan, Can. J. Earth Sci., 7, 1384-1401, 1970.

Shimizu, D., N. Imoto, and M. Musashino, Permian and Triassic sedimentary history of the Honshu geosyncline in the Tanba belt, Southwest Japan, J. Phys. Earth, 26, suppl. S, 337-344, 1978.

Shimizu, H., and A. Masuda, Cerium in chert as an indication of marine environment of its formation, Nature, 266, 346-348, 1977.

Sugisaki, R., K. Yamamoto, and M. Adachi, Triassic bedded cherts in central Japan are not pelagic, Nature, 298, 644-647, 1982.

Suwa,k., Metamorphic rocks occurring along the Median Tectonic Line in the Japanese Islands: Ryoke and Sanbagawa belts, in The Median Tectonic Line, edited by R. Sugimura, pp. 221-237, Tokai University Press, Tokyo, 1973.

Tanaka, K., Kanoashi group, an olistostrome in the Nichihara area, Shimane prefecture, J. Geol. Soc. Jpn., 86, 613-628, 1980.

Tanaka, K., and T. Nozawa, Geology and mineral resources of Japan, $430 \mathrm{pp}$., Geological Survey of Japan, Tokyo, 1977.

Tanba Belt Research Group, Paleozoic and Mesozoic systems in the Tanba belt, 4 , Lithofacies and structure of the Tanba group at the northwestern hills of Kyoto city, Earth Sci. Tokyo, 33, $137-143,1979$.

Tazawa, J., Y. Aita, T. Yuki, and K. Otsuki, Discovery of Permian radiolarian from the "non-calcareous strata" of Omi, central Japan, Earth Sci. Tokyo, 38, 264-267, 1984.

Teraoka, Y., Paleozoic and Mesozoic formations in the southern area of Nariwa machi, Okayama prefecture, with special reference to the upper Triassic Nariwa group, J. Geol. Soc. Jpn., 65, 494-504, 1959.

Toyohara, F., Early Mesozoic tectonic development of the Northwestern Chichibu geosyncline in West Chugoku, 
Japan, J. Fac. Sci. Univ. Tokyo, 19 (4), 253-334, 1977.

Uemura, T., and Y. Yokota, Deformation facies of the folded Jurassic Kuruma group, central Japan, Earth Sci. Tokyo, 35, 41-48, 1981.

Uyeda, S., and A. Miyashiro, Plate tectonics and the Japanese Islands: a synthesis, Geol. Soc. Am. Bull., 85, 1159-1170, 1974.

Wang, Y., and D. Sun, A survey of the Jurassic system of China, Can. J. Earth Sci. 20, 1646-1656, 1983.

Yabe, H., Probable position of the outer wing of the Ryoke metamorphics in Southwest Japan, J. Geogr. Soc. Tokyo, 72, 110-114, 1963.

Yamaguchi, M., and T. Yanagi Geochronology of some metamorphic rocks in Japan, Eclogae Geol. Helv., 63, $371-388,1970$.

Yao, A., Radiolarian fauna from the Mino belt in the Northern part of the Inuyama area, Central Japan, I: Spongosaturnalids, J. Geosci. Osaka City Univ. 15, 21-64, 1972.

Yoshida, M., Pre-Ryoke orthogneiss in the Ryoke belt, Japan, Res. Rep. Lower Paleozoic-Upper Proterozoic, B, pp. 27-30, Assoc. Geol. Coop. Jpn. 1981.

Yu, K. M., Sedimentological study on the early Jurassic shallow marine facies in Southwest Japan and the comparison with Daedong supergroup in South Korea, Mem. Fac. Sci. Kyoto Univ., Ser. Geol. Mineral., 49, 1-62, 1983.

M. Caridroit, J. Charvet, and M. Faure, Dept. Sciences de la Terre, Université d'Orléans, 45046 Orléans, France.

(Received May 4, 1985;

revised June 1, 1986;

accepted June 13, 1986.) 